\title{
Synaptically Released Zinc Triggers Metabotropic Signaling via a Zinc-Sensing Receptor in the Hippocampus
}

\author{
Limor Besser, ${ }^{1,3 *}$ Ehud Chorin, ${ }^{1,3 *}$ Israel Sekler, ${ }^{2,3}$ William F. Silverman, ${ }^{1,3}$ Stan Atkin, ${ }^{4}$ James T. Russell, ${ }^{4}$ and \\ Michal Hershfinkel 1,3 \\ Departments of ${ }^{1}$ Morphology and ${ }^{2}$ Physiology and ${ }^{3}$ Zlotowski Center, Ben Gurion University, Beer-Sheva 84105, Israel, and ${ }^{4}$ Section for Cell Biology and \\ Signal Transduction, National Institute of Child Health and Human Development-National Institutes of Health, Bethesda, Maryland 20892-4480
}

$\mathrm{Zn}^{2+}$ is coreleased with glutamate from mossy fiber terminals and can influence synaptic function. Here, we demonstrate that synaptically released $\mathrm{Zn}^{2+}$ activates a selective postsynaptic $\mathrm{Zn}^{2+}$-sensing receptor $(\mathrm{ZnR})$ in the CA3 region of the hippocampus. $\mathrm{ZnR}$ activation induced intracellular release of $\mathrm{Ca}^{2+}$, as well as phosphorylation of extracellular-regulated kinase and $\mathrm{Ca}^{2+} / \mathrm{calmodulin}^{2} \mathrm{kinase} \mathrm{II}$. Blockade of synaptic transmission by tetrodotoxin or $\mathrm{CdCl}$ inhibited the $\mathrm{ZnR}$-mediated $\mathrm{Ca}^{2+}$ rises. The responses mediated by $\mathrm{ZnR}$ were largely attenuated by the extracellular $\mathrm{Zn}^{2+}$ chelator, CaEDTA, and in slices from mice lacking vesicular $\mathrm{Zn}^{2+}$, suggesting that synaptically released $\mathrm{Zn}^{2+}$ triggers the metabotropic activity. Knockdown of the expression of the orphan G-protein-coupled receptor 39 (GPR39) attenuated ZnR activity in a neuronal cell line. Importantly, we observed widespread GPR39 labeling in CA3 neurons, suggesting a role for this receptor in mediating $\mathrm{ZnR}$ signaling in the hippocampus. Our results describe a unique role for synaptic $\mathrm{Zn}^{2+}$ acting as the physiological ligand of a metabotropic receptor and provide a novel pathway by which synaptic $\mathrm{Zn}^{2+}$ can regulate neuronal function.

\section{Introduction}

Histochemically reactive or "free" $\mathrm{Zn}^{2+}$ in the brain is mostly localized within glutamatergic synaptic vesicles in the hippocampus and in a variety of forebrain areas (Frederickson and Moncrieff, 1994). Uptake of $\mathrm{Zn}^{2+}$ ions into synaptic vesicles is mediated by the $\mathrm{Zn}^{2+}$ transporter, zinc transporter 3 ( $\mathrm{ZnT} 3$ ), and deletion of the gene encoding it results in the elimination of the synaptic $\mathrm{Zn}^{2+}$ pool (Palmiter et al., 1996; Cole et al., 1999). At mossy fiber synapses, $\mathrm{Zn}^{2+}$ is coreleased with glutamate in an activity-dependent manner (Vogt et al., 2000; Qian and Noebels, 2005). The hippocampal mossy fibers, by virtue of their high concentration of synaptic $\mathrm{Zn}^{2+}$ and their well defined circuitry, have been the focus of many of the studies on the role of $\mathrm{Zn}^{2+}$ in the CNS.

While increases in intracellular free $\mathrm{Zn}^{2+}$ (Sensi et al., 1999) have been associated with neuronal death (Aizenman et al., 2000; McLaughlin et al., 2001; Sensi and Jeng, 2004; Zhang et al., 2004), a physiological role for synaptically released $\mathrm{Zn}^{2+}$ is still largely unknown. Prior work has focused primarily on the function of synaptic $\mathrm{Zn}^{2+}$ as a modulator of ionotropic receptors. For example, it has been shown that $\mathrm{Zn}^{2+}$ modifies the activity of postsynaptic NMDA receptors through interactions with specific low

Received 0ct. 22, 2008; revised Dec. 23, 2008; accepted Dec. 26, 2008.

This work was supported by United States-Israel Binational Science Foundation Grant 2003201 (M.H., J.T.R.), a Rich Foundation grant, and Israel Science Foundation Grant 585/05 (M.H.). We thank Dr. Richard Palmiter for the ZnT3 KO mice, Dr. Meredin Stoltenberg for advice on the ZnT3 KO experiments, and Drs. Elias Aizenman and Edi Barkai for valuable discussions and critical reading of this manuscript. We thank Astellas Pharma Inc. for generously providing the $\mathrm{G} \alpha \mathrm{q}$ inhibitor YM-254890.

${ }^{*}$ L.B. and E.C. contributed equally to this work.

Correspondence should be addressed to Michal Hershfinkel, Department of Morphology, Faculty of Health Sciences, Ben Gurion University, P.0. Box 653, Beer-Sheva 84105, Israel. E-mail: hmichal@bgu.ac.il.

DOI:10.1523/JNEUROSCI.5093-08.2009

Copyright $\odot 2009$ Society for Neuroscience $\quad$ 0270-6474/09/292890-12\$15.00/0 and high affinity binding sites (Paoletti et al., 1997; Rachline et al., 2005; Izumi et al., 2006). Additionally, zinc ions have been shown to block the activity of $\mathrm{GABA}_{\mathrm{A}}$ receptors (Hosie et al., 2003; Ruiz et al., 2004). Synaptic plasticity has thus been reported to be affected by $\mathrm{Zn}^{2+}$ by shaping NMDA (Vogt et al., 2000) or GABA synaptic potentials (Ruiz et al., 2004), by modulating assembly of the postsynaptic density (Gundelfinger et al., 2006), or by regulating long-term potentiation (LTP) (Li et al., 2001; Huang et al., 2008). Despite these findings, $\mathrm{Zn}^{2+}$-dependent allosteric regulation of ionotropic pathways may not fully explain how endogenous $\mathrm{Zn}^{2+}$ is linked to all these physiological processes (Paoletti et al., 2009).

Metabotropic receptors play a critical role in synaptic transmission (Nicholls et al., 2006). These receptors mediate slow synaptic potentials, activate intracellular signaling pathways, and indirectly modulate ion channels and transporters. Metabotropic receptors (mGluRs) are also involved in changes in synaptic plasticity via activation of the mitogen-activated protein (MAP) kinase pathways and in the regulation of gene expression (Volk et al., 2006). Activation of the mossy fibers has been shown to induce intracellular $\mathrm{Ca}^{2+}$ release from postsynaptic CA3 neurons via a metabotropic pathway (Kapur et al., 2001). Although synaptic $\mathrm{Zn}^{2+}$ is released in this region, a role for this ion in metabotropic signaling has heretofore not been demonstrated.

We previously characterized a $\mathrm{Zn}^{2+}$-sensing receptor, $\mathrm{ZnR}$, in epithelial cells, which induces release of intracellular $\mathrm{Ca}^{2+}$ mediated by a $\mathrm{G} \alpha \mathrm{q}$-protein through the $\mathrm{IP}_{3}$ pathway (Hershfinkel et al., 2001). In the present study, we demonstrate that synaptic $\mathrm{Zn}^{2+}$ specifically triggers metabotropic activity in the CA3 hippocampal region through activation of a $\mathrm{ZnR}$. Our results also suggest that the orphan G-protein-coupled receptor 39 (GPR39) mediates neuronal $\mathrm{ZnR}$ activity. 


\section{Materials and Methods}

Slice preparation. Experimental procedures were performed in accordance with protocols approved by the committee for the Ethical Care and Use of Animals in Research at Ben Gurion University. After decapitation, brains were quickly removed and placed into ice-cold $\left(4^{\circ} \mathrm{C}\right)$ artificial CSF (ACSF). Coronal slices, $400 \mu \mathrm{m}$ thick, from mice postnatal day 8 (P8) to P16, were produced on a vibrating microtome (Campden Instruments) as described previously (Qian and Noebels, 2005; Frederickson et al., 2006). Slices were maintained at room temperature in ACSF for $1 \mathrm{~h}$, containing the following (in mM): $124 \mathrm{NaCl}, 3 \mathrm{KCl}, 1.25 \mathrm{NaH}_{2} \mathrm{PO}_{4}, 26$ $\mathrm{NaHCO}_{3}, 10$ dextrose, $2 \mathrm{MgSO}_{4}$, and $2 \mathrm{CaCl}_{2}$, saturated with $95 \% \mathrm{O}_{2}$ and $5 \% \mathrm{CO}_{2}$.

Cell culture and GPR39 silencing. Human neuroblastoma cells, SHSY5Y, were cultured in DMEM as described previously (Kan et al., 2007). Cells were seeded on $10 \mathrm{~mm}$ glass coverslips to $80 \%$ confluency and imaged after $24 \mathrm{~h}$ as described below. For gene silencing experiments, cells were cotransfected with the silencing plasmids, $3 \mu \mathrm{g}$ of shGPR39 or shT1R3, and $1 \mu \mathrm{g}$ YFP plasmid in $35 \mathrm{~mm}$ plates, using Lipofectamine 2000 as described by the manufacturer (Invitrogen), and imaged $48 \mathrm{~h}$ after transfection. The target sequence of the GPR39 for shRNA was CCATGGAGTTCTACAGCATtt and that of T1R3 was CUUAGGAUGAAGGGGGACUtt.

Fluorescence imaging. Slices were loaded with the $\mathrm{Ca}^{2+}$ indicator Fura-2 A.M. ( $25 \mu \mathrm{M}$, TefLabs) for imaging experiments, or Fluo-4 A.M. (25 $\mu \mathrm{M}$, Invitrogen), for confocal analysis, in the presence of $0.02 \%$ pluronic acid for $20 \mathrm{~min}$, as described previously (Beierlein et al., 2002). The imaging system consisted of an upright fluorescence microscope (Olympus BX51; Olympus Optical), Polychrome II monochromator (TILL Photonics) and a SensiCam cooled charge-coupled device (PCO). Fluorescence imaging measurements were acquired with Imaging Workbench 2 (Axon Instruments) as described previously (Hershfinkel et al., 2001). The ratio of the Fura-2 fluorescence response excited at 340 and $380 \mathrm{~nm}$ was determined. Representative traces from each experiment, averaged over $\sim 60$ cells from at least 3 slices \pm SEM are shown. In some experiments, the intracellular $\mathrm{Ca}^{2+}$ concentration was determined by calibration of intracellular $\mathrm{Ca}^{2+}$ in slices superfused with the calcium ionophore, Bromo-A23187, in the presence of $5 \mathrm{~mm} \mathrm{Ca}^{2+}\left(R_{\max }\right)$ or 5 mM EGTA $\left(R_{\min }\right)$, as described previously (Grynkiewicz et al., 1985; Hershfinkel et al., 2001), using a $K_{\mathrm{d}}$ of $220 \mathrm{~nm}$ (for Fig. $1, R_{\max }=1.56$ and $R_{\min }=0.84$, and for Fig. 6, $R_{\max }=1.62$ and $\left.R_{\min }=0.89\right)$.

Because calcium stores are often rapidly depleted, and store refilling may take several seconds, and because ZnR activity may undergo rapid desensitization, repetitive application of $\mathrm{Zn}^{2+}$ or electrical stimuli were avoided. We therefore monitored $\mathrm{Ca}^{2+}$ responses triggered by only a single stimulation per slice. If required, cells were preincubated in ACSF containing $\mathrm{Zn}^{2+}$ (for the desensitization protocol) or inhibitors before imaging. Slices were imaged within 15-30 min after loading with the intracellular dye, except for the desensitization experiment which required extended time for the recovery of the intracellular $\mathrm{Ca}^{2+}$. In some of the experiments, the fluorescence response after stimulation remained at an elevated plateau or was followed by a slow rise, an effect that was more apparent in the presence of inhibitors, since the signal was attenuated but this nonrelated, elevated plateau persisted. This elevated fluorescence may arise from several factors, including activation of the store operated channels, continuous release of $\mathrm{Ca}^{2+}$ from the $\mathrm{IP}_{3}$ sensitive store (Bianchi et al., 1999; Nakamura et al., 2000), or slow permeation of $\mathrm{Zn}^{2+}$, or $\mathrm{Cd}^{2+}$ (see Fig. $6 \mathrm{~A}$ ) via voltage sensitive $\mathrm{Ca}^{2+}$ channels, leading to Fura-2 fluorescence (Hinkle et al., 1987).

The change in the fluorescence response, " $\Delta \mathrm{R}$," was determined by subtracting the maximal signal after stimulation from the baseline signal. The $\Delta \mathrm{R}$ (the number of slices for each experiment is indicated in the figure legend) was averaged and is presented in the bar graphs. Statistical analyses were performed using a student's $t$ test, compared with control or ANOVA with post hoc comparisons as relevant.

For studying the metal selectivity of the receptor, the $\Delta \mathrm{R}$ was obtained after application of each heavy metal in the presence or absence of the $\mathrm{G} \alpha \mathrm{q}$ inhibitor. The $\Delta \mathrm{R}$ obtained in the presence of the inhibitor was subtracted from the $\Delta \mathrm{R}$ measured in its absence, to eliminate the fluo- rescence response triggered via Gq-independent pathways. Thus, we determined the residual $\mathrm{G} \alpha \mathrm{q}$-dependent fluorescent response triggered by the ions, which was marked as $\Delta \mathrm{R}_{\mathrm{Gq}}$ inhibitor.

Confocal imaging analysis was performed using slices loaded with the $\mathrm{Ca}^{2+}$ indicator, Fluo-4 (5 $\left.\mu \mathrm{M}\right)$. Images were acquired by a Zeiss LSM 510 system using a $20 \times$ objective ( $488 \mathrm{~nm}$ excitation). Changes in Fluo- 4 signal were monitored after the application of $\mathrm{Zn}^{2+}$ and subsequently slices were washed and stained on stage with Sulforhodamine 101, SR101 (Sigma, $1 \mu \mathrm{M}$ in ACSF) (Nimmerjahn et al., 2004) for $2 \mathrm{~min}$. The slices were subsequently rinsed in ACSF and imaged at an excitation wavelength of $540 \mathrm{~nm}$.

Fluorescence imaging of cultured cells was performed as described previously (Hershfinkel et al., 2001). Cells were loaded with Fura-2 (3 $\mu \mathrm{M}$ ) for $20 \mathrm{~min}$ and allowed to recover for $30 \mathrm{~min}$. Transfected cells were identified by monitoring YFP fluorescence (excitation at $480 \mathrm{~nm}$ ) and $\mathrm{Ca}^{2+}$ signals were monitored and averaged only on the transfected cells.

Mossy fiber stimulation. Transverse slices were prepared from mice at P8-P16 as described above, and imaged within 60-90 min to avoid synaptic $\mathrm{Zn}^{2+}$ depletion (Yin et al., 2002; Frederickson et al., 2006). Slices were loaded with Fura-2 as described above and intracellular $\mathrm{Ca}^{2+}$ imaging was performed by digitally acquiring the fluorescent images every $3 \mathrm{~s}$. A bipolar tungsten electrode placed near the hilus of the dentate gyrus was used to stimulate mossy fibers. Electrical stimuli $(66 \mathrm{~Hz}, 100$ $\mu \mathrm{A}$ for $150 \mathrm{~ms}$, total of 10 pulses) were delivered to the mossy fibers using Master-8 stimulator unit (A.M.P.I.), and intracellular $\mathrm{Ca}^{2+}$ was monitored in the CA3 hippocampal region.

Desensitization protocol. Slices were pretreated with $75 \mu \mathrm{M} \mathrm{Zn}{ }^{2+}$ for 15 $\mathrm{min}$, washed, and allowed to recover in ACSF for 60-100 min. Control slices were treated with ACSF for the same time period. Slices were then loaded with Fura- 2 and imaged using the same protocol as above. Finally, $\mathrm{Zn}^{2+}(300 \mu \mathrm{M})$ was reapplied and the $\mathrm{Ca}^{2+}$ response compared between control and $\mathrm{Zn}^{2+}$-pretreated slices.

Immunohistochemical analysis. For GPR39 labeling, mice were perfused intracardially with $1 \%$ sodium sulfide in PBS $(50 \mathrm{ml})$ followed by $4 \%$ paraformaldehyde in PBS $(50 \mathrm{ml})$ and $5 \mu \mathrm{m}$ paraffin-embedded sections were prepared. Sections were then deparaffinized in xylene and rehydrated in decreasing concentrations of ethanol. Antigen retrieval was achieved by boiling the slide-mounted sections in $0.01 \mathrm{~m}$ citric acid buffer, $\mathrm{pH}$ 6.0, in a microwave for $10 \mathrm{~min}$. The sections were then rinsed in PBS, incubated in blocking solution for $30 \mathrm{~min}$ in room temperature, and incubated overnight in primary antibody. The following dilutions were used: rabbit anti-GPR39 (Novus Biological, 1:1000); NeuN (NeuN Alexa 488, Millipore, 1:500) and MAP2 (Santa Cruz Biotechnology, 1:200), at room temperature. After rinsing in PBS, the sections were incubated for $1 \mathrm{~h}$ with affinity-purified cy2 or cy3-conjugated goat antirabbit IgG (The Jackson Laboratory), rinsed in PBS, and mounted with anti-fade solution (Kierrkegaard). The tissue was imaged in a confocal microscope (Zeiss LSM 510) with $488 \mathrm{~nm}$ or $543 \mathrm{~nm}$ excitation wavelength for cy2 and cy3 staining, respectively.

For kinase phosphorylation analysis, $400 \mu \mathrm{m}$ slices were incubated with $\mathrm{Zn}^{2+}$ (100 $\mu \mathrm{M}$ for 90 or $180 \mathrm{~s}$ ). Some slices were pretreated with the $\mathrm{G} \alpha \mathrm{q}$ inhibitor (1 $\mu \mathrm{M}, \mathrm{YM}-254890,10 \mathrm{~min})$ or the ionotropic glutamate receptor (iGluR) inhibitors, CNQX $(20 \mu \mathrm{M})$ and AP5 $(50 \mu \mathrm{M})$, and the $\mathrm{Ca}^{2+}$ channel blocker, nimodipine $(1 \mu \mathrm{M})$. Immunohistochemical analysis was performed as described previously (Sekler et al., 2002). Briefly, slices were frozen in OCT embedding media (Tissue-TEK), sectioned on a cryostat $(10 \mu \mathrm{m})$ and fixed in $4 \%$ paraformaldehyde at room temperature (20 min). Sections were rinsed in PBS, incubated in blocking solution for $30 \mathrm{~min}$ at room temperature, and then incubated for $3 \mathrm{~h}$ with anti-phosphorylated extracellular regulated kinase (pERK1/2) (SigmaAldrich) at 1:100 or overnight with anti-phosphorylated $\mathrm{Ca}^{2+} /$ calmodulin kinase (pCaMKII) (Santa Cruz Biotechnology, 1:200). This was followed by $1 \mathrm{~h}$ incubation in Cy3-conjugated secondary antibody (The Jackson Laboratory). Immunolabeled sections were mounted with DAPI-containing mounting medium (Immunomount) and viewed in a Zeiss Axiomat microscope equipped with appropriate fluorescence barrier and excitation filters or in a Zeiss LSM 510 confocal microscope. Images were analyzed and digitally captured into the ImageJ analysis software to quantify pERK1/2 or pCaMKII phosphorylation, and nor- 
malized to the respective DAPI staining to control for the number of cells in the region of interest. The images were assigned false color scales and superimposed with Adobe Photoshop 7.0 software (Adobe Systems). Graphs represent mean of the normalized fluorescence determined from at least 3 regions obtained from three independent experiments \pm SEM.

\section{Results}

A metabotropic response is triggered by $\mathrm{Zn}^{2+}$

To determine if $\mathrm{Zn}^{2+}$ activates metabotropic signaling in the brain, we used coronal hippocampal slices. Cells were loaded with Fura- 2 and treated with $\mathrm{Zn}^{2+}$ by direct delivery into the ACSF perfusate. Ap-

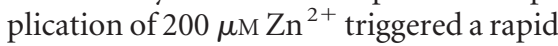
increase in Fura-2 fluorescence in the pyramidal cell layer of the CA3 hippocampal region (Fig. $1 A, B$ ) in the presence or absence of extracellular $\mathrm{Ca}^{2+}$. This response was similar to that induced by ATP (300 $\mu \mathrm{M}$, see inset), shown previously to trigger a metabotropic purinergic response (Yamazaki et al., 2002). After application of $\mathrm{Zn}^{2+}$, the decline to resting $\mathrm{Ca}^{2+}$ levels was somewhat slower in the presence of extracellular $\mathrm{Ca}^{2+}$, possibly due to $\mathrm{Ca}^{2+}$ influx via the store-operated $\mathrm{Ca}^{2+}$ channel, activated after store depletion (Wu et al., 2004). Because $\mathrm{Zn}^{2+}$ can permeate into neurons and because Fura- 2 has a high affinity for this ion $\left(K_{\mathrm{d}}=2 \mathrm{nM}\right)$, it was important to establish that the fluorescence signal observed was related to changes in intracellular $\mathrm{Ca}^{2+}$ and not $\mathrm{Zn}^{2+}$. Endoplasmic reticulum (ER) $\mathrm{Ca}^{2+}$ stores were depleted, using the $\mathrm{ER} \mathrm{Ca}^{2+}$ pump inhibitor, thapsigargin (TG, $1 \mu \mathrm{M}$ ), applied with the purinergic agonist ATP $(300 \mu \mathrm{M})$ to enhance intracellular $\mathrm{Ca}^{2+}$ release. Subsequent applications of $\mathrm{Zn}^{2+}$ $(200 \mu \mathrm{M})$ (Fig. 1C,D) failed to elicit an increase in Fura- 2 signal $(10 \pm 2 \%$ of response in control), indicating that the fluorescence response is not mediated by $\mathrm{Zn}^{2+}$ permeation, but rather by release of $\mathrm{Ca}^{2+}$ from TG-sensitive stores. We then assessed the $\mathrm{Zn}^{2+}$ concentration dependence of the observed $\mathrm{Ca}^{2+}$ rise (Fig. $1 E$ ). The $\mathrm{Zn}^{2+}$-dependent $\mathrm{Ca}^{2+}$ response was observed over a wide range of $\mathrm{Zn}^{2+}$ concentrations (i.e., from tens to hundreds micromolar) with an apparent $K_{\mathrm{m}}$ of $146 \pm 26 \mu \mathrm{M}$. Together, these results indicate that $\mathrm{Zn}^{2+}$ triggers an intracellular $\mathrm{Ca}^{2+}$ signal in the $\mathrm{CA} 3$ region, which is extracellular $\mathrm{Ca}^{2+}$ independent, and mediated by $\mathrm{Ca}^{2+}$ release from TG-sensitive stores (Fig. 1D).

We next asked if the $\mathrm{Zn}^{2+}$-induced $\mathrm{Ca}^{2+}$ signal is mediated through a Gq-coupled receptor and via the $\mathrm{IP}_{3}$ pathway, both characteristic of the described previously ZnR-mediated responses in non-neuronal cells (Hershfinkel et al., 2001). Application of $200 \mu \mathrm{M} \mathrm{Zn^{2+ }}$ after treatment with the phospholipase $\mathrm{C}$ (PLC) inhibitor U73122 (1 $\mu \mathrm{M})$ resulted in a $\mathrm{Ca}^{2+}$ rise that was inhibited by $77 \pm 3 \%$ compared with control. In the presence of the inactive analog of this inhibitor U73343 (1 $\mu \mathrm{M})$ the $\mathrm{Zn}^{2+}$ dependent response was similar $(92 \pm 11 \%)$ to control (Fig. $2 A, B)$. The G $\alpha$ q inhibitor YM-254890 ( $1 \mu \mathrm{M})$ (Sharir and Hershfinkel, 2005) inhibited the $\mathrm{Zn}^{2+}$-dependent $\mathrm{Ca}^{2+}$ response by $68 \pm 4 \%$ compared with control (Fig. 2 B). Since mGluRs mediate metabotropic signaling in this region, we compared the $\mathrm{Zn}^{2+}$-dependent response in the presence or absence of mGluR inhibitors. To ascertain that the mGluRs were blocked, saturating concentrations of the inhibitors were used (Nakamura et al., 2000), and their efficacy was also verified by monitoring their ability to block the $\mathrm{Ca}^{2+}$ response triggered by the group I mGluR agonist DHPG (( $S)$-3,5-dihydroxyphenylglycine) (Bianchi et al., 1999). Application of the mGluR5 inhibitor MPEP (2-methyl-6-(phenylethynyl)-pyridine; $5 \mu \mathrm{M}$ ), with the mGluR1 

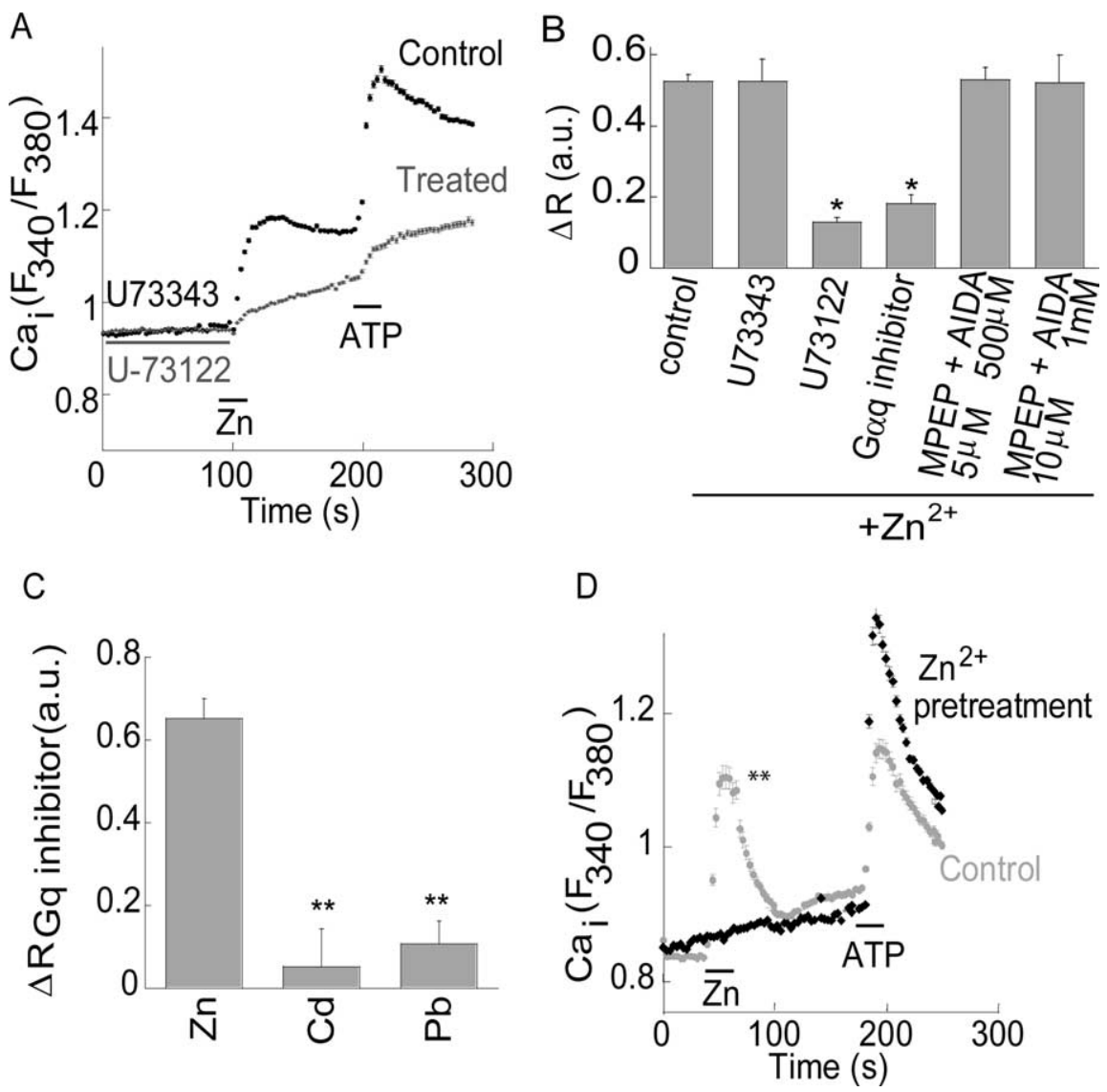

Figure 2. The $\mathrm{Ca}^{2+}$ rise triggered by $\mathrm{Zn}^{2+}$ is mediated by a Gq- and PLC-dependent pathway. $\boldsymbol{A}$, Slices were pretreated (as marked) with the PLC inhibitor U73122 (1 $\mu \mathrm{M}$, active form) or its inactive derivative U73343 (1 $\mu \mathrm{M}$, control) and Zn ${ }^{2+}(200 \mu \mathrm{M})$ was applied. As control, ATP (300 $\mu \mathrm{m})$ was subsequently applied. The $\mathrm{Ca}^{2+}$ signal (Fura-2) is shown. B, The averaged $\mathrm{Ca}^{2+}$ rise triggered by $\mathrm{Zn}^{2+}$ in the presence of the inhibitors of PLC (U73122, $\left.1 \mu \mathrm{m}\right)$ or $\mathrm{G} \alpha \mathrm{q}(\mathrm{YM}-254890,1 \mu \mathrm{m})$ or the mGluR1 and 5 inhibitors (AIDA and MPEP, respectively) at the indicated concentrations ( ${ }^{* *} p<0.01, n=20$ for control and $n=9$ for all other treatments). $C$, The fluorescent response observed after application of $\mathrm{Cd}^{2+}$ and $\mathrm{Pb}^{2+}$ were monitored in the absence or presence of the $G \alpha q$ inhibitor $(1 \mu \mathrm{m}, \mathrm{YM}-254890)$. The difference $\left(\Delta R_{\mathrm{Gq}}\right.$ inhibitor $)$ between the response in the presence or absence of the inhibitor is shown (** $p<0.01, n=5$ ). D, Slices were pretreated with $75 \mu \mathrm{mZn}{ }^{2+}$ or ACSF for $15 \mathrm{~min}$, washed, and allowed to recover in ACSF for $60-100 \mathrm{~min}$. $\mathrm{Zn}^{2+}(300 \mu \mathrm{m})$ was then reapplied while monitoring the $\mathrm{Ca}^{2+}$ response. As control, ATP $(300 \mu \mathrm{M})$ was subsequently applied $(* * p<0.01, n=7)$.

inhibitor AIDA (1-aminoindan-1,5-dicarboxylic acid; $500 \mu \mathrm{M})$, attenuated the $\mathrm{Ca}^{2+}$ signal induced by $100 \mu \mathrm{M}$ DHPG by $62 \pm$ $6 \%(n=8)$, while $10 \mu \mathrm{M}$ MPEP in the presence of $1 \mathrm{mM}$ AIDA reduced the DHPG-dependent response by $69 \pm 5 \%(n=8)$. In contrast, the $\mathrm{Zn}^{2+}$-dependent $\mathrm{Ca}^{2+}$ signal was not reduced at either concentration of the mGluR inhibitors $(p>0.3)$ (Fig. $2 B$ ), suggesting that the $\mathrm{Zn}^{2+}$-triggered response is not related to mGluRs, but is mediated via a distinct metabotropic pathway. The metal selectivity of the metabotropic response was then assessed, focusing on $\mathrm{Cd}^{2+}$ and $\mathrm{Pb}^{2+} \cdot \mathrm{Cd}^{2+}$ is a group IIB metal, like $\mathrm{Zn}^{2+}$, which binds with high affinity to $\mathrm{Zn}^{2+}$ binding sites on proteins such as metallothionein (Henkel and Krebs, 2004). $\mathrm{Pb}^{2+}$ is a divalent metal that has been shown to alter synaptic function (White et al., 2007). To avoid background effects mediated by permeation of the ions, and to resolve if these ions trigger the metabotropic $\mathrm{Ca}^{2+}$ response, we determined the difference between the maximal Fura-2 signal, triggered by $\mathrm{Cd}^{2+}, \mathrm{Pb}^{2+}$ or $\mathrm{Zn}^{2+}$, in the presence or absence of the $\mathrm{G} \alpha \mathrm{q}$ inhibitor $\left(\Delta \mathrm{R}_{\mathrm{Gq}}\right.$ inhibitor, see Materials and Methods). As shown in Figure $2 C$, the $\mathrm{Zn}^{2+}$-dependent Fura- 2 response was largely blocked by the $\mathrm{G} \alpha \mathrm{q}$ inhibitor $(1 \mu \mathrm{M})$, yielding a $\Delta \mathrm{R}_{\mathrm{Gq}}$ inhibitor $=0.65 \pm 0.05$. In contrast, the inhibitor did not significantly reduce $\mathrm{Cd}^{2+}$ or $\mathrm{Pb}^{2+}$ - dependent fluorescence $\left(\Delta \mathrm{R}_{\mathrm{Gq}}\right.$ inhibitor $=$ $0.05 \pm 0.09$ or $0.1 \pm 0.05$, respectively). This indicates that $\mathrm{Cd}^{2+}$ and $\mathrm{Pb}^{2+}$ do not induce a metabotropic $\mathrm{Ca}^{2+}$ rise, and that the $\mathrm{ZnR}$ response is selective for $\mathrm{Zn}^{2+}$.

Previous work in our lab has shown that the epithelial $\mathrm{ZnR}$ undergoes profound functional desensitization after prolonged exposure to $\mathrm{Zn}^{2+}$ at concentrations which can activate the $\mathrm{ZnR}$ (AzrielTamir et al., 2004; Sharir and Hershfinkel, 2005). Such a regulatory mechanism would be especially relevant in the CNS, considering the pathophysiological implications of sustained activation of the $\mathrm{IP}_{3}$ pathway (Tang et al., 2003), and the potential excessive release of synaptic $\mathrm{Zn}^{2+}$ during intense excitatory activity (Weiss et al., 2000). To determine if $\mathrm{Zn}^{2+}$-dependent signaling in neurons undergoes desensitization, slices were pretreated with $75 \mu \mathrm{M}$ $\mathrm{Zn}^{2+}$ for $15 \mathrm{~min}$ and then washed in ACSF (see Materials and Methods). We subse-

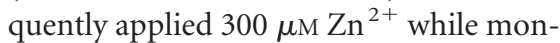
itoring the $\mathrm{Ca}^{2+}$ response. The $\mathrm{Zn}^{2+}$ and ATP-dependent $\mathrm{Ca}^{2+}$ response observed in the control slices (pretreated with ACSF) is smaller than that shown in Figure $2 B$, and may result from the prolonged interval before imaging. The $\mathrm{Zn}^{2+}$ dependent $\mathrm{Ca}^{2+}$ response in slices that were pre-exposed to $\mathrm{Zn}^{2+}$ was only $15 \pm$ $2 \%$ compared with control (Fig. 2D) $(\Delta \mathrm{R}=0.33 \pm 0.02$ in control compared with $0.05 \pm 0.01$ in the $\mathrm{Zn}^{2+}$ pretreated slices), while application of ATP triggered a robust $\mathrm{Ca}^{2+}$ rise (Fig. $2 \mathrm{D}$ ). As shown, ATP-induced $\mathrm{Ca}^{2+}$ responses were somewhat larger in $\mathrm{Zn}^{2+}$-desensitized preparations, likely due to the fact that intracellular stores had not been depleted by a ZnRmediated response. Together, these results indicate that the $\mathrm{Zn}^{2+}$-dependent metabotropic response triggered in the CA3 region is mediated through a Gq-coupled receptor via the $\mathrm{IP}_{3}$ pathway, and undergoes a $\mathrm{Zn}^{2+}$-dependent desensitization similar to that described previously for the epithelial $\mathrm{ZnR}$.

To determine whether neurons or glia exhibit metabotropic $\mathrm{Zn}^{2+}$-dependent $\mathrm{Ca}^{2+}$ release, $\mathrm{Zn}^{2+}$ was applied as before and the $\mathrm{Ca}^{2+}$ response monitored in a confocal microscope (Fig. $3 A$ ). Slices were subsequently stained with the astroglial marker SR101 (Sulforhodamine 101) (Nimmerjahn et al., 2004). As shown in Figure $3 B$, cells which exhibited a $\mathrm{Zn}^{2+}$-dependent $\mathrm{Ca}^{2+}$ rise (white arrows) were not labeled with the astrocyte marker, SR101 suggesting that ZnR activity is not found in astroglia. To further address this issue, we asked if $\mathrm{ZnR}$ activity is observed in an established neuronal cell line, SH-SY5Y, a subclone of the SK$\mathrm{N}-\mathrm{SH}$ cell line. SH-SY5Y cells were previously used to study neurite outgrowth, cell growth and glutamate toxicity (Canals et al., 2005; Smith et al., 2009). As shown in Figure 3C, application of $200 \mu \mathrm{M} \mathrm{Zn}{ }^{2+}$, a concentration which triggered robust $\mathrm{ZnR}$ activity in the slices (Fig. 1), was also followed by an intracellular $\mathrm{Ca}^{2+}$ rise in the SH-SY5Y cells. When SH-SY5Y cells were treated with the G $\alpha$ q inhibitor, YM-254890 (1 $\mu \mathrm{M})$, the $\mathrm{Zn}^{2+}$-induced $\mathrm{Ca}^{2+}$ 
response was inhibited by $95 \pm 3 \%$ compared with control (Fig. $3 C)(\Delta \mathrm{R}=0.61 \pm$ 0.15 in control and $0.03 \pm 0.01$ in the presence of the inhibitor), indicating that the $\mathrm{Zn}^{2+}$-dependent $\mathrm{Ca}^{2+}$ response is mediated via a Gq-dependent pathway.

MAP and CAM kinase pathways are activated by metabotropic $\mathrm{Zn}^{2+}$-dependent signaling Activation of extracellular regulated kinase $(\mathrm{ERK} 1 / 2)$ and $\mathrm{Ca}^{2+} /$ calmodulindependent protein kinase (CaMKII) play fundamental roles in hippocampal synaptic plasticity and neuronal survival (Hansen et al., 2003; Giovannini, 2006; Luo and DeFranco, 2006; Cohen-Matsliah et al., 2007). Because intracellular $\mathrm{Ca}^{2+}$ rise can activate these pathways (Berkeley and Levey, 2003), we sought to determine if the $\mathrm{Zn}^{2+}$-dependent metabotropic response could trigger ERK1/2 or CaMKII phosphorylation in neurons. As shown in Figure $4, A$ and $B$, application of $\mathrm{Zn}^{2+}$ (100 $\mu \mathrm{M}, 90 \mathrm{~s}$ ) led to a fourfold increase in pERK $1 / 2$ in the CA3 region compared with control. Colocalization with DAPI using confocal microscopy indicated that pERK1/2 staining was abundant in the nuclear and perinuclear regions (Fig. 4A, bottom). Application of blockers of the iGluRs $(20 \mu \mathrm{M}$ CNQX and $50 \mu \mathrm{M}$ AP5) (Fig. $4 \mathrm{~B}$ ), and the $\mathrm{Ca}^{2+}$ channel blocker, nimodipine $(1 \mu \mathrm{m})$, did not attenuate the $\mathrm{Zn}^{2+}$-dependent phosphorylation of ERK1/2, indicating that it is mediated by extracellular $\mathrm{Zn}^{2+}$ and not by its potential permeation through these pathways. As illustrated in Figure 4, $C$ and $D$, application of $\mathrm{Zn}^{2+}$ also resulted in an increase of $\sim 50 \%$ in phosphorylated CaMKII. Finally, to assess the role of the metabotropic pathway in mediating $\mathrm{Zn}^{2+}$-dependent kinase phosphorylation, slices were treated with the G $\alpha$ q inhibitor YM$254890(1 \mu \mathrm{M})$ before application of $\mathrm{Zn}^{2+}$. As shown in Figure 4, application of the $\mathrm{G} \alpha \mathrm{q}$ inhibitor reduced the $\mathrm{Zn}^{2+}$-dependent phosphorylation of both ERK1/2 and CaMKII to baseline levels. Together, our results indicate that a $\mathrm{G} \alpha \mathrm{q}$-coupled pathway mediates $\mathrm{Zn}^{2+}$-dependent ERK1/2 and CaMKII phosphorylation in the CA3 region of the hippocampus.

\section{GPR39 mediates neuronal $\mathrm{Zn}^{2+}$-dependent signaling}

It was recently suggested that a member of the ghrelin receptor family of GPCRs, namely GPR39, can be activated by serum $\mathrm{Zn}^{2+}$ (Yasuda et al., 2007). The physiological significance of the $\mathrm{Zn}^{2+}$ dependent signal mediated by GPR39 activation remains unclear, however (Holst et al., 2007; Yasuda et al., 2007). We hypothesized that GPR39 might be the ZnR itself and thus sought to determine if it mediates neuronal $\mathrm{Zn}^{2+}$-dependent signaling. The endogenous expression of GPR39 was initially determined by immunoblot analysis of the neuronal SH-SY5Y cells (Fig. 5A). This cell line is particularly useful for ectopic expression of genes and RNA constructs because of the high transfection efficiency that is typically achieved. A short hairpin RNA (shGPR39) construct targeted to silence GPR39 efficiently lowered GPR39 expression in these cells, as deter-

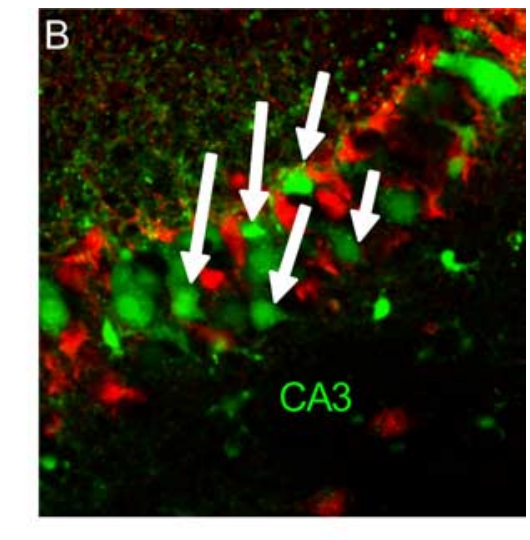

Time (s)

150
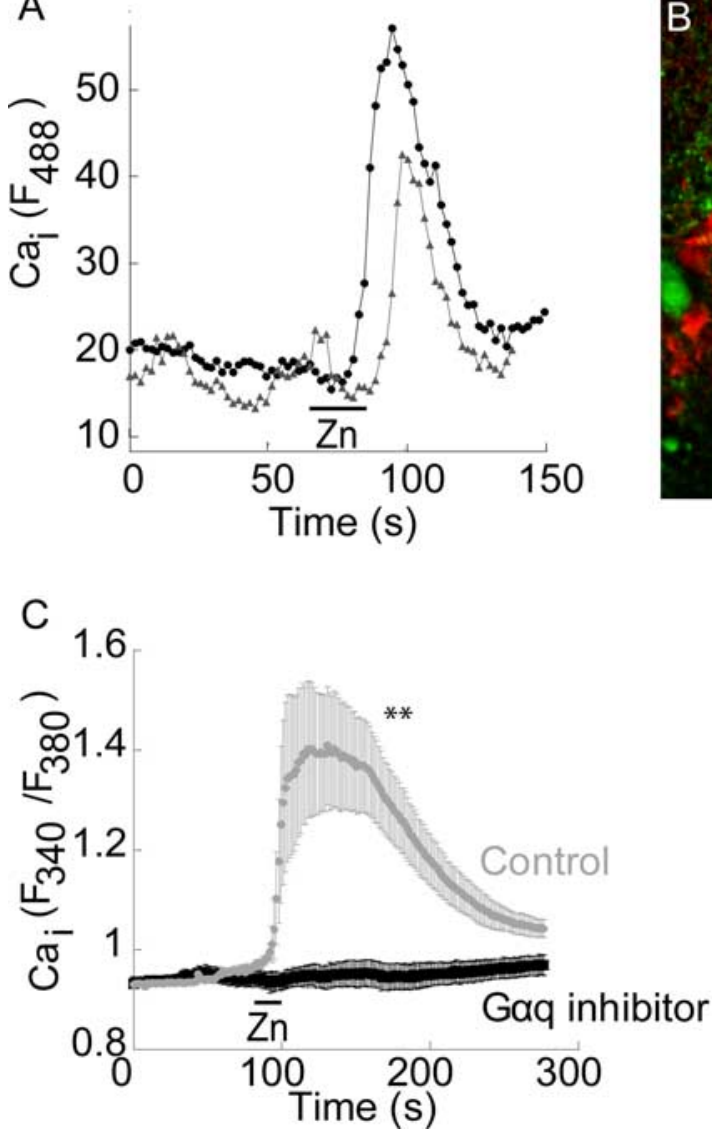

Figure 3. $\mathrm{Zn}^{2+}$-dependent $\mathrm{Ca}^{2+}$ rise is monitored in $\mathrm{CA} 3$ neurons but not in astrocytes. $A$, Confocal microscope analysis of is shown. $\boldsymbol{B}$, Cells that showed $\mathrm{Zn}^{2+}$-dependent $\mathrm{Ca}^{2+}$ rise were indicated (arrows) and subsequently SR101 (1 $\mu \mathrm{m}$ ) was added to mark astroglia cells (red). $C, \mathrm{Zn}^{2+}(200 \mu \mathrm{M})$ was applied to SH-SY5Y neuronal cells loaded with Fura-2 in the absence or presence of the $\mathrm{G}_{\alpha q}$ inhibitor $\left(1 \mu \mathrm{M}\right.$ YM-254890) $\left({ }^{* *} p<0.01, n=9\right)$.

mined by immunoblot analysis (Fig. $5 A$ ). As a control, a hairpin construct targeted against T1R3, a closely related GPCR, did not alter GPR39 expression in SH-SY5Y cells (Fig. 5A). The $\mathrm{Ca}^{2+}$ response to application of $\mathrm{Zn}^{2+}$ was then monitored in SH-SY5Y cells transfected with shGPR39 or in cells transfected with either shT1R3 or with an empty vector. As shown in Figure 5, B and $C$, the $\mathrm{Zn}^{2+}$ dependent $\mathrm{Ca}^{2+}$ response was similar in vector and shT1R3expressing cells, but significantly attenuated (by $73 \pm 7 \%$ ) in cells transfected with shGPR39. We then asked whether GPR39 was endogenously expressed in the hippocampus. Immunofluorescent labeling of GPR39 (Fig. 5D) was observed as punctuate staining at the periphery of cells expressing the neuronal nuclear marker (NeuN) in CA3. Some punctuate staining was also observed near dendrites in the $\mathrm{CA} 3$ region (Fig. $5 D$, inset). This suggests that GPR39 is present on the cells that exhibit $\mathrm{Zn}^{2+}$-dependent metabotropic activity. These results are consistent with the hypothesis that GPR39 may mediate ZnR signaling in CA3 neurons.

\section{Synaptic $\mathrm{Zn}^{2+}$ triggers $\mathrm{ZnR}$-dependent response in the CA3 region}

While the experiments described above strongly support the notion that a metabotropic receptor is activated in neurons in the $\mathrm{CA} 3$ region by exogenous $\mathrm{Zn}^{2+}$, induction of the $\mathrm{Ca}^{2+}$ response by synaptically released $\mathrm{Zn}^{2+}$ is required to demonstrate the physiological significance of this phenomenon. To address this issue, synaptic $\mathrm{Zn}^{2+}$ release was induced by electrical stimulation 

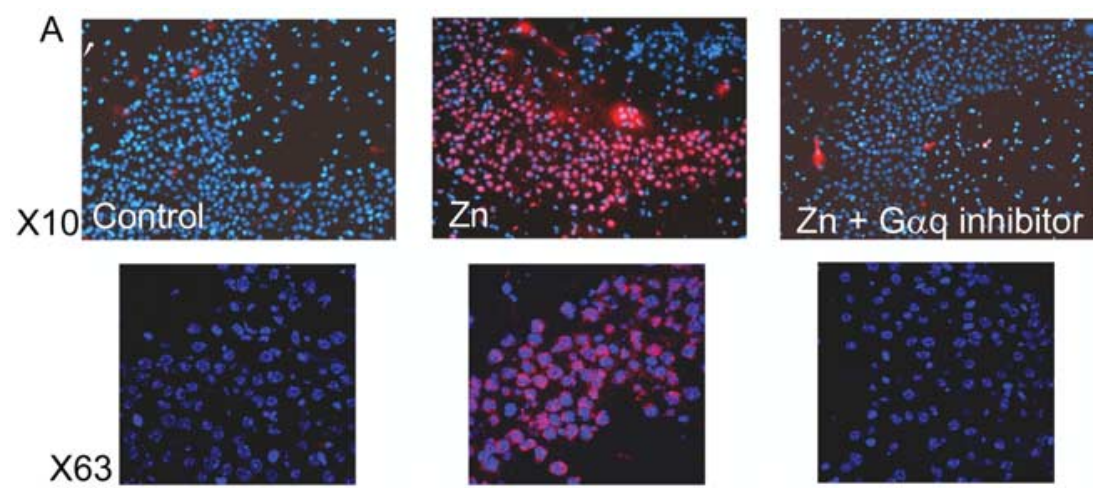

B
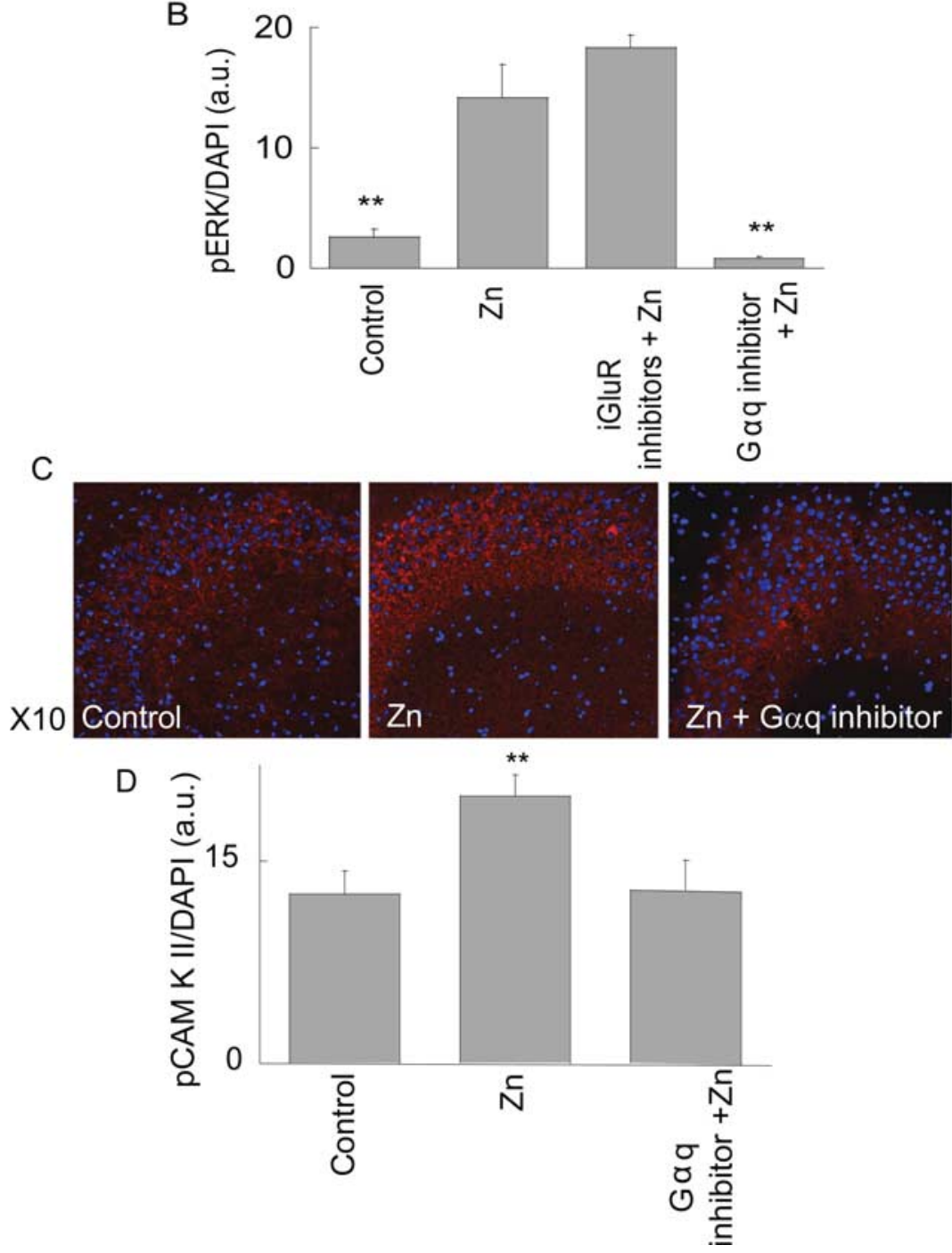

Figure 4. The metabotropic $\mathrm{Zn}^{2+}$-dependent response is followed by phosphorylation of ERK1/2 and CaMKII in the CA3 region. $A, \mathrm{Zn}^{2+}(100 \mu \mathrm{m}, 90 \mathrm{~s})$ was applied to slices in the presence or absence of the $\mathrm{G}_{\alpha q}$ inhibitor (1 $\left.\mu \mathrm{m}, \mathrm{YM}-254890\right)$. Slices were then reacted with pERK1/2 antibody, shown in red, and DAPI (blue). Images acquired at $\times 10$ (top) and $\times 63$ (confocal, bottom) are shown. $\boldsymbol{B}$, Quantitative analysis of ERK1/2 phosphorylation normalized to DAPI staining in the CA3 region. Shown is the phosphorylation after application of $\mathrm{Zn}^{2+}$ in the absence or presence of the ionotropic glutamate inhibitors (CNQX, $20 \mu \mathrm{m}$ and AP5, $50 \mu \mathrm{M})$ and $\mathrm{Ca}^{2+}$ channel blocker (nimodipine $\left.1 \mu \mathrm{M}\right)$, or the $\mathrm{G}_{\alpha \mathrm{q}}$ inhibitor $(1 \mu \mathrm{M} \mathrm{YM}-254890)\left({ }^{* *} p<0.01, n=6\right)$. C, Slices treated with $\mathrm{Zn}^{2+}(100 \mu \mathrm{m}, 3 \mathrm{~min})$, in the presence or absence of the $\mathrm{G}_{\alpha \mathrm{q}}$ inhibitor, were then reacted with pCaMKII antibodies (red) and DAPI (blue). D, Quantitative analysis of pCaMKII staining normalized to DAPI staining $\left({ }^{* *} p<0.01, n=6\right)$.

of the mossy fibers using a protocol consisting of 10 pulses at 66 $\mathrm{Hz}$ (Fig. 6A) while monitoring intracellular $\mathrm{Ca}^{2+}$ changes in CA3 neurons. As shown in Figure $6 B$, a robust increase in intracellular $\mathrm{Ca}^{2+}$ concentration was triggered after the electrical stimulation.
This response was blocked by application of the voltage-gated $\mathrm{Na}^{+}$-channel blocker tetrodotoxin $(1 \mu \mathrm{M}, 91 \pm 3 \%$ inhibition compared with control) (Fig. 6B,D). We also applied $\mathrm{CdCl}(200 \mu \mathrm{M})$ at a concentration that did not attenuate a metabotropic signal triggered by ATP (data not shown) yet is known to effectively inhibit the $\mathrm{Ca}^{2+}$-channels that govern synaptic release (Hinkle et al., 1987; Rosenmund and Stevens, 1996). Similar to the effect of tetrodoxin (TTX), application of $\mathrm{CdCl}$ inhibited the fluorescence response in the CA3 cells after stimulation of the mossy fibers (Fig. 6B,D) (86 $\pm 5 \%$ inhibition compared with control), suggesting that the metabotropic $\mathrm{Ca}^{2+}$ response in the CA3 region is triggered by synaptic transmission. Application of the $\mathrm{G} \alpha \mathrm{q}$ inhibitor YM-254890 $(1 \mu \mathrm{M})$ also resulted in a $92 \pm$ $4 \%$ inhibition of the responses, compared with control slices (Fig. $6 B, D$ ). The inhibitory action of YM-254890 indicates that a Gq-coupled receptor triggers the $\mathrm{Ca}^{2+}$ response in the CA3 neurons after mossy fiber stimulation. The observed $\mathrm{Ca}^{2+}$ signals occurred over a range of several seconds, characteristic of metabotropic receptor-mediated physiological responses (Fig. 1) (Kapur et al., 2001). Inhibitors of iGluRs, namely CNQX $(20 \mu \mathrm{M})$ and AP5 $(50 \mu \mathrm{M})$, failed to attenuate the $\mathrm{Ca}^{2+}$ rise (Fig. 6C). Finally, in slices that were treated with AIDA and MPEP, inhibitors, respectively, of mGluR1 and mGluR5, the $\mathrm{Ca}^{2+}$ response triggered by the electrical stimulation was reduced by $\sim 50 \%$, compared with the response in control slices (Fig. 6D). A similar inhibitory effect was observed in slices treated with both the mGluR and iGluR inhibitors ( $1 \mathrm{~mm}$ AIDA, $10 \mu \mathrm{M}$ MPEP, $20 \mu \mathrm{M}$ CNQX and $50 \mu \mathrm{M}$ AP5). Thus, a significant, residual metabotropic $\mathrm{Ca}^{2+}$ response persisted in the presence of mGluR inhibitors, while the $\mathrm{G} \alpha \mathrm{q}$ inhibitor completely inhibited this response (Fig. 6D). This suggests that after synaptic release a receptor distinct from the mGluRs is responsible for a substantial metabotropic $\mathrm{Ca}^{2+}$ response in CA3.

To assess the role of $\mathrm{Zn}^{2+}$ in triggering the synaptically mediated metabotropic $\mathrm{Ca}^{2+}$ response, electrical stimulation was performed in the presence of the cellimpermeable $\mathrm{Zn}^{2+}$ chelator, CaEDTA, which does not significantly affect extracellular $\mathrm{Ca}^{2+}$ concentration (Qian and Noebels, 2005). As shown in Figure 7, A and $B$, in the presence of $10 \mu \mathrm{M}$ CaEDTA, the $\mathrm{Ca}^{2+}$ response within the CA3 layer was only slightly lower than that in control. However, an inhibitory effect was observed in the presence of either $150 \mu \mathrm{M}$ or $1 \mathrm{~mm}$ CaEDTA (Fig. $7 B$ ) (inhibition of $51 \pm 5 \%$ 
or $54 \pm 7 \%$, respectively, compared with control). This indicates that synaptically released $\mathrm{Zn}^{2+}$ mediates a major part of the metabotropic $\mathrm{Ca}^{2+}$ response. The relatively short time required to induce the metabotropic effect indicates that CaEDTA is unlikely to affect this signaling by regulating the protein expression pattern, as was previously demonstrated for GluR2 activation (Calderone et al., 2004). Finally, we asked if the mGluR inhibitors together with the chelator have an additive effect in blocking the metabotropic $\mathrm{Ca}^{2+}$ response. As shown in Figure $7 B$, the metabotropic signal after electrical stimulation of the mossy fibers in the presence of the mGluR inhibitors ( $1 \mathrm{mM}$ AIDA and $10 \mu \mathrm{M}$ MPEP) and CaEDTA $(150 \mu \mathrm{M})$ was attenuated by $84 \pm 6 \%$. Thus, the coapplication of the chelator together with the mGluR inhibitors yielded a significantly smaller response than that monitored in the presence of either CaEDTA $(p<0.05)$ or the inhibitors alone $(p<0.05)$.

Mice deficient in ZnT3 lack synaptic $\mathrm{Zn}^{2+}$ while maintaining apparently normal synaptic activity, including release of glutamate and GABA (Cole et al., 2000, 2001; Lopantsev et al., 2003). In agreement with previous studies (Qian and Noebels, 2005), we observed that stimulation of the mossy fibers was followed by a significantly lower fluorescence signal by the extracellular $\mathrm{Zn}^{2+}$. sensitive dye, Newport green $(1 \mu \mathrm{M})$, in slices from ZnT3 knock-out (KO) mice compared with wild-type controls (data not shown). These mice can thus serve as a useful model to determine the role of synaptic $\mathrm{Zn}^{2+}$ in activating the $\mathrm{ZnR}$ and subsequent metabotropic $\mathrm{Ca}^{2+}$ signaling. The $\mathrm{Ca}^{2+}$ response after stimulation of the mossy fibers in slices from $\mathrm{ZnT} 3 \mathrm{KO}$ mice was $56 \pm 7 \%$ of the response in slices from wild-type (WT) mice (Fig. 7C). Thus, in slices from mice lacking synaptic $\mathrm{Zn}^{2+}$, we observed $\sim 45 \%$ inhibition of the metabotropic signaling in CA3 (Fig. 7D), similar to the reduction of the metabotropic signal by CaEDTA in WT mice (Fig. $7 B$ ). Application of exogenous $\mathrm{Zn}^{2+}$ to slices from the $\mathrm{ZnT} 3 \mathrm{KO}$ mice, however, was followed by a $\mathrm{Ca}^{2+}$ rise $(108 \pm 7 \%)$ similar to WT controls (Fig. 7D). This $\mathrm{Ca}^{2+}$ response triggered by exogenous $\mathrm{Zn}^{2+}$ in slices from $\mathrm{ZnT} 3 \mathrm{KO}$ mice indicates that the lack of synaptic $\mathrm{Zn}^{2+}$, rather than a deficiency of $\mathrm{ZnR}$, is responsible for the attenuated metabotropic response. Application of CaEDTA $(150 \mu \mathrm{M})$ to slices from $\mathrm{ZnT} 3 \mathrm{KO}$ mice yielded $\mathrm{a} \mathrm{Ca}^{2+}$ response that did not significantly differ from the response obtained in nontreated ZnT3 KO slices (Fig. 7 E, F). Finally, application of the mGluR inhibitors, using the same experimental paradigm described in Figure $6 D$, was followed by a $\mathrm{Ca}^{2+}$ response that was much smaller than the response in the nontreated, $\mathrm{ZnT} 3 \mathrm{KO}$ slices (Fig. $7 F)(73 \pm 3 \%$ inhibition). Thus, the mGluR inhibitors exhibit significantly $(p<0.01)$ greater inhibition of the response in ZnT3 KO slices than their effect in the WT slices. The inhibitory effect of neurons (scale bar, $10 \mu \mathrm{m}$ )
A
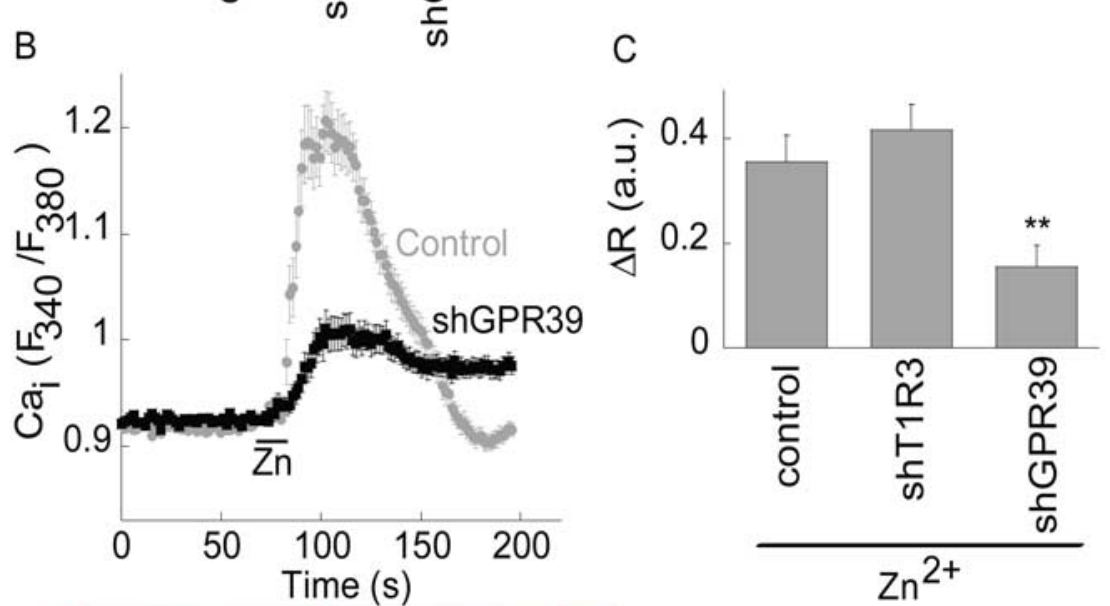

Figure 5. ZnR signaling is mediated by GPR39. A, Western blot analysis of GPR39 expression in SH-SY5Y cells transfected with control vector, shGPR39 or shT1R3 plasmids. $\boldsymbol{B}$, The $\mathrm{Ca}^{2+}$ response after application of $\mathrm{Zn}^{2+}(100 \mu \mathrm{m})$ in cells transfected with the shGPR39 or vector (control). C, Quantitative analysis of the $\mathrm{Zn}^{2+}$-dependent $\mathrm{Ca}^{2+}$ rise in cells transfected with the shGPR39, shT1R3 or control $\left({ }^{* *} p<0.01, n=9\right.$ ). $\boldsymbol{D}$, Confocal images of GPR39 labeling (red) and the neuronal marker NeuN (green) in the (bottom right). Insert shows staining of the dendritic marker MAP2 (green) combined with GPR39 labeling (red) in the CA3

the extracellular $\mathrm{Zn}^{2+}$ chelator in slices from the WT, but not the ZnT3 KO mice, together with the substantially attenuated metabotropic $\mathrm{Zn}^{2+}$ response in the $\mathrm{ZnT} 3 \mathrm{KO}$ mice, support the conclusion that synaptic $\mathrm{Zn}^{2+}$, released from mossy fiber terminals, activates a $\mathrm{ZnR}$ and triggers $\mathrm{Ca}^{2+}$ signaling in CA3 neurons of the hippocampus.

\section{Discussion}

Previous studies have suggested that synaptic $\mathrm{Zn}^{2+}$ is a neuromodulator, acting allosterically at ionotropic synaptic receptors (Vogt et al., 2000; Smart et al., 2004; Paoletti et al., 2009). The present work demonstrates, for the first time, that $\mathrm{Zn}^{2+}$ specifically activates metabotropic signaling in neurons, and does so via a $\mathrm{Zn}^{2+}$-sensing receptor. This finding is supported by the atten- 
A
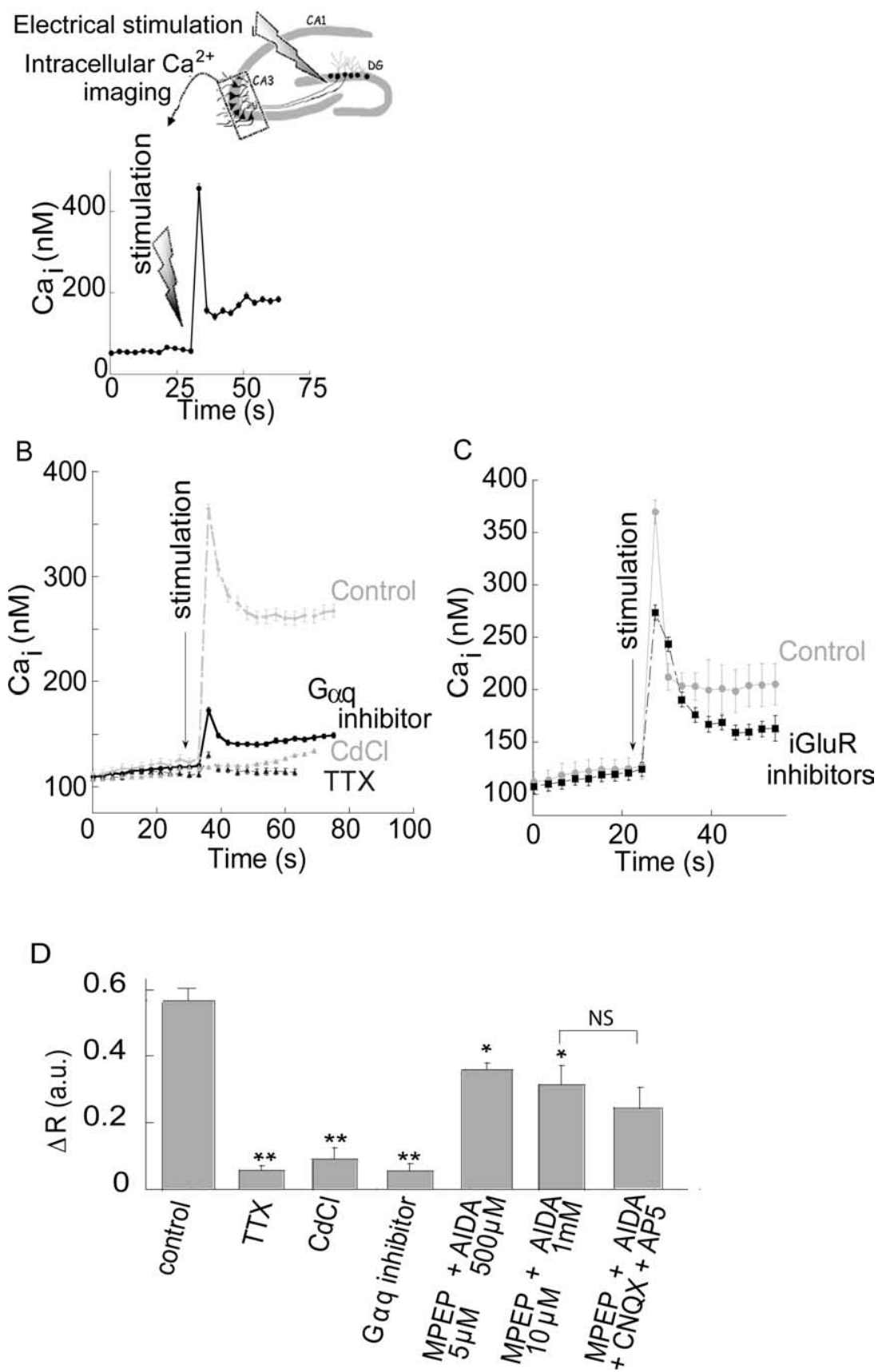

Figure 6. Mossy fiber stimulation triggers a metabotropic $\mathrm{Ca}^{2+}$ rise that is partially independent of the mGluRs. $A$, Schematic representation of the experimental setup for electrical stimulation. A stimulating electrode was placed at the mossy fiber axons, nearthe dentate gyrus (DG) and the Fura-2 signal was monitored in the CA3 pyramidal cell layer. Shown is a representative time lapse $\mathrm{Ca}^{2+}$ signal acquired from a single cell, after electrical stimulation $(66 \mathrm{~Hz}, 100 \mu \mathrm{A}$ for $150 \mathrm{~ms}$, total of 10 pulses) of the mossy fibers at the marked time. $\boldsymbol{B}$, The $\mathrm{Ca}^{2+}$ response in the CA3 region after electrical stimulation of the mossy fibers in the presence or absence of the $\mathrm{G}_{\alpha q}$ inhibitor $(1 \mu \mathrm{M}$, YM-254890), with the voltage-gated $\mathrm{Na}^{+}$-channel blocker TTX (1 $\left.\mu \mathrm{M}\right)$, or with the voltage-gated Ca ${ }^{2+}$ channel blocker CdCl (200 $\left.\mu \mathrm{M}\right)$. Representative responses averaged over 25 cells in 1 slice. C, Slices were treated with the iGluR inhibitors (CNQX, $20 \mu \mathrm{m}$ and AP5, 50 $\mu \mathrm{m}$ ) subsequently the mossy fibers were stimulated and the $\mathrm{Ca}^{2+}$ response is shown. Representative responses averaged over 24 cells in 1 slice. $\boldsymbol{D}$, The averaged responses of the $\mathrm{Ca}^{2+}$ rise triggered after electrical stimulation of the mossy fibers in control slices $(n=23)$ or in slices treated with $\operatorname{TTX}(n=6), \mathrm{CdCl}(n=6)$, the $\mathrm{G}_{\alpha q}$ inhibitor $(n=6)$, the mGluR1 and 5 inhibitors (AIDA and MPEP, respectively, $n=$ 6) or the mGluRs inhibitors together with the iGluRs inhibitors (1 mm AIDA, $10 \mu \mathrm{MMPEP}, 20 \mu \mathrm{m}$ CNQX and $50 \mu \mathrm{m} \mathrm{AP5,} n=4)\left({ }^{*} p<0.05\right.$, ${ }^{* *} p<0.01$; NS, nonsignificant).

uation of the $\mathrm{Zn}^{2+}$-dependent $\mathrm{Ca}^{2+}$ rise after depletion of $\mathrm{Ca}^{2+}$ stores in the $\mathrm{ER}$, and after inhibition of the $\mathrm{IP}_{3}$ pathway using a $\mathrm{G} \alpha \mathrm{q}$ inhibitor or PLC blocker. A role for the $\mathrm{IP}_{3}$ pathway in $\mathrm{ZnR}$ signaling is consistent with a previous study suggesting that metabotropic signaling in the $\mathrm{CA} 3$ region is $\mathrm{IP}_{3}$-dependent rather than rayonidinereceptor dependent (Kapur et al., 2001). The lack of a $\mathrm{Zn}^{2+}$-dependent $\mathrm{Ca}^{2+}$ rise in cells labeled by the astroglial marker, SR101, suggests that although glial cells express metabotropic receptors, the $\mathrm{Zn}^{2+}$. dependent metabotropic response is mediated primarily by neurons.

Our results indicate that the transient metabotropic $\mathrm{Ca}^{2+}$ response in CA3 neurons is triggered by synaptically released $\mathrm{Zn}^{2+}$ after mossy fiber stimulation. The $\mathrm{Ca}^{2+}$ response triggered by electrical stimulation was inhibited by blockade of synaptic transmission. Furthermore, the response is attenuated in the presence of an extracellular $\mathrm{Zn}^{2+}$ chelator, CaEDTA, or in slices from mice lacking synaptic $\mathrm{Zn}^{2+}$. The synaptic $\mathrm{Zn}^{2+}$-dependent $\mathrm{Ca}^{2+}$ response was also mediated via a Gqcoupled mechanism. We conclude, therefore, that in addition to glutamate, metabotropic signaling in the CA3 cells is mediated by synaptically released $\mathrm{Zn}^{2+}$.

We used CaEDTA at concentrations sufficient to remove $\mathrm{Zn}^{2+}$ from the extracellular milieu, based on steady state conditions (http://www.stanford.edu/ cpatton/webmaxc/webmaxcS.htm) and the expected concentration of released- $\mathrm{Zn}^{2+}$ (Vogt et al., 2000; Qian and Noebels, 2005). At low concentration of the chelator $(10 \mu \mathrm{M})$, no significant effect on $\mathrm{ZnR}$ activity was apparent. This is consistent with the fact that $\mathrm{ZnR}$ is not activated by baseline concentrations of extracellular $\mathrm{Zn}^{2+}$, because of its relative low affinity $\left(K_{\mathrm{m}} \sim 150 \mu \mathrm{M}\right)$ (Fig. 1), unlike the high affinity $\mathrm{Zn}^{2+}$ binding sites on the NMDA receptor (Qian and Noebels, 2005). In the presence of $150 \mu \mathrm{M}$ or $1 \mathrm{~mm}$ CaEDTA, however, the $\mathrm{ZnR}$ response was reduced. In previous studies, CaEDTA, at similar concentrations, did not effectively reduce a transient rise in extracellular $\mathrm{Zn}^{2+}$ because of its slow chelation activity (Qian and Noebels, 2005). The effective inhibition of the $\mathrm{ZnR}$ response is probably related to the relatively low affinity of the $\mathrm{ZnR}$ to $\mathrm{Zn}^{2+}$, suggesting such that even partial reduction of extracellular $\mathrm{Zn}^{2+}$ will suffice to lower its concentration below the threshold of ZnR. Such reduction in extracellular $\mathrm{Zn}^{2+}$ may not be apparent using high affinity $\mathrm{Zn}^{2+}$-sensitive dyes. In addition, metabotropic receptors are often distantly located from the release site of neurotransmitters (Knöpfel and Uusisaari, 2008), as we also show for the GPR39 (Fig. 5). Thus, prolonged diffusion time of $\mathrm{Zn}^{2+}$ toward its receptor may enable more effective chelation of $\mathrm{Zn}^{2+}$ by CaEDTA.

While some studies have suggested that synaptic $\mathrm{Zn}^{2+}$ does 
not affect activity-dependent plasticity, but rather, reshapes the NMDA response (Vogt et al., 2000), others support an effect of synaptic $\mathrm{Zn}^{2+}$ on modulation of longterm synaptic changes in the hippocampus (Xie and Smart, 1994; Li et al., 2001; Izumi et al., 2006). Furthermore, synaptic $\mathrm{Zn}^{2+}$ was shown previously to facilitate LTP in fear conditioning pathways by attenuating GABAergic inhibition (Kodirov et al., 2006). Recently, synaptic $\mathrm{Zn}^{2+}$ was suggested to enhance mossy fiber LTP by activating intracellular signaling of TrkB receptors (Huang et al., 2008; Nagappan et al., 2008). Interestingly, TrkB signaling is strongly regulated by GPCRs, via signaling pathway similar to that activated by $\mathrm{ZnR}$ (Hwang et al., 2005; Chen et al., 2007). It has also been reported that TrkB is activated by extracellular $\mathrm{Zn}^{2+}$ through regulation of metalloproteases (Hwang et al., 2005). An intriguing question remains whether $\mathrm{ZnR}$ links synaptic $\mathrm{Zn}^{2+}$ to regulation of LTP.

Our results indicate that extracellular $\mathrm{Zn}^{2+}$, via the $\mathrm{ZnR}$, activates mitogenactivated protein kinase (MAPK) and CaMKII pathways. Activation of the MAPK pathway by intracellular $\mathrm{Zn}^{2+}$ rise (Seo et al., 2001; Harris et al., 2004), or after oxidative or nitrosative stress (McLaughlin et al., 2001; Du et al., 2003; Zhang et al., 2004, 2007), is associated with neuronal death. In contrast, activation of MAPK by extracellular $\mathrm{Zn}^{2+}$, in neurons, has been shown to be anti-apoptotic (An et al., 2005). Activation of CaMKII has also been linked to neuronal survival, and inactivation of CaMKII during seizure increases neuronal cell death (Hansen et al., 2003). Zinc has been shown to activate CaMKII (Lengyel et al., 2000), while an extracellular $\mathrm{Zn}^{2+}$ chelator suppressed CaMKII activity in the hippocampus (Tan and Chen, 1997). In the absence of synaptic $\mathrm{Zn}^{2+}$, hippocampal CA3 neurons are more vulnerable to seizure-induced cell death (Domínguez et al., 2003; Côté et al., 2005), consistent with a prosurvival role for ZnR-dependent activation of MAPK and CaMKII. Finally, both the MAPK and CaMKII pathways are critical players in synaptic plasticity, involved in hippocampal learning and memory (Rosenblum et al., 2002; Miyamoto, 2006). Our results show that $\mathrm{Zn}^{2+}$, applied for a shortduration (i.e., $90 \mathrm{~s}$ ), induces translocation of pERK $1 / 2$ to the nucleus.

Changes in expression and function of metabotropic glutamate receptors appear to be critical factors in the etiology of epileptic seizures (Pitsch et al., 2007). Interestingly, chelation of synaptic $\mathrm{Zn}^{2+}$, as well as dietary $\mathrm{Zn}^{2+}$ deficiency, are associated with increased susceptibility to seizures (Fukahori and Itoh,

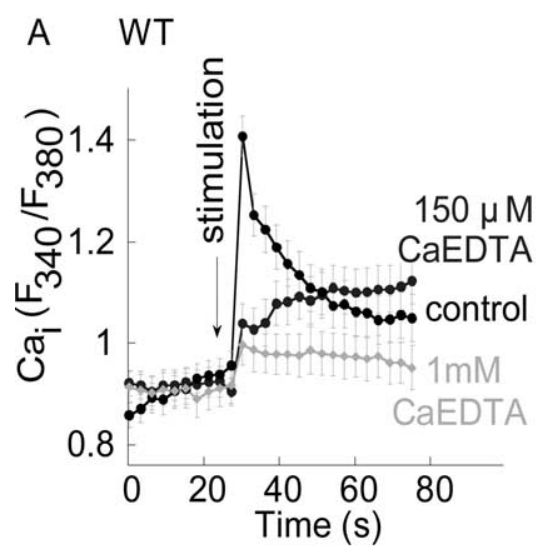

B WT
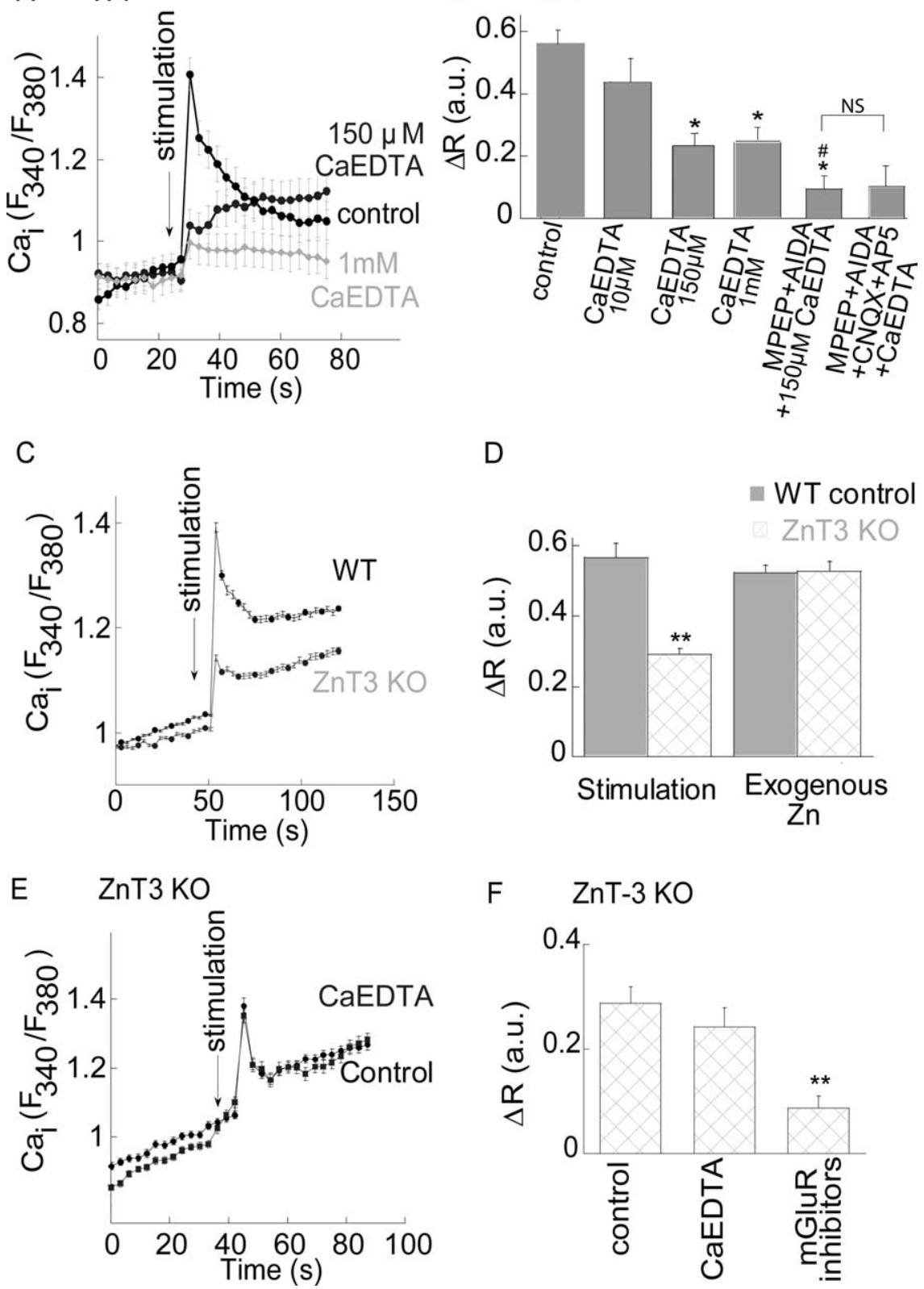

F $\quad$ ZnT-3 KO

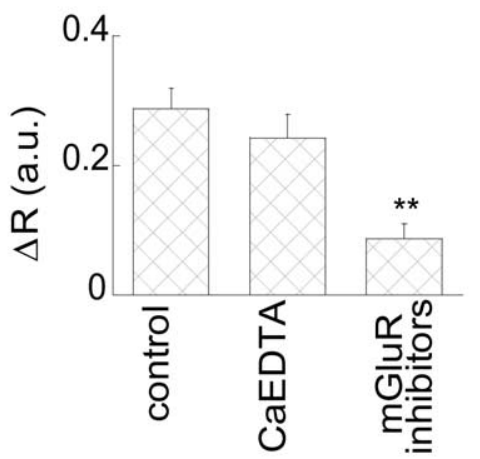

Figure 7. The metabotropic $\mathrm{Ca}^{2+}$ response is attenuated in the absence of synaptic $\mathrm{Zn}^{2+} . A$, The $\mathrm{Ca}^{2+}$ response in cells in the $\mathrm{CA} 3$ region after electrical stimulation of the mossy fibers in the presence or absence of the extracellular $\mathrm{Zn}^{2+}$ chelator CaEDTA at the indicated concentrations. Representative responses averaged over 28 cells in 1 slice. $\boldsymbol{B}$, The averaged $\mathrm{Ca}^{2+}$ response in the presence or absence of CaEDTA $(n=9)$ at the indicated concentration, or $150 \mu \mathrm{m}$ CaEDTA in the presence of the mGluR inhibitors $(n=6)$, or CaEDTA with the mGluR and iGluR inhibitors $(n=4)\left({ }^{*} p<0.05\right.$ compared with control and ${ }^{\#} p<0.05$ compared with CaEDTA alone; NS, nonsignificant). The control is the same as in Figure $6 D$. C, The response of cells in the CA3 region after electrical stimulation of the mossy fibers in slices obtained from $\mathrm{ZnT} 3 \mathrm{KO}$ versus $\mathrm{WT}$, control, mice. Representative responses averaged over 23 cells in 1 slice. $\boldsymbol{D}$, Summary of the $\mathrm{Ca}^{2+}$ responses triggered in slices from the $\mathrm{ZnT} 3 \mathrm{KO}$ and WT mice after electrical stimulation or the application of exogenous $\mathrm{Zn}^{2+}$ using the paradigm described in Figure 1 ( $^{* *} p<0.01, n=11$ for each treatment, the WT control is the same as in Fig. $6 D$ for the stimulation induced response and to Fig. $2 B$ for the exogenous $Z n^{2+}$ application). $E$, The $\mathrm{Ca}^{2+}$ rise triggered in slices from the ZnT3 KO mice in the presence or absence of CaEDTA. Representative response averaged over 26 cells in 1 slice. $F$, Averaged response after electrical stimulation of the mossy fibers in slices from ZnT3 KO mice in the presence of CaEDTA $(n=7)$ or the mGluR inhibitors (500 $\mu$ M AIDA, $5 \mu \mathrm{MMPEP}, n=7)\left({ }^{* *} p<0.01\right)$.

1990; Domínguez et al., 2003). These effects complement the phenotype of the ZnT3 knock-out mice, which are more susceptible to kainate-induced seizures (Cole et al., 2000). At present, it is unclear how synaptic $\mathrm{Zn}^{2+}$ is related to seizure activity. The involvement of $\mathrm{Zn}^{2+}$ in modulating GABA and NMDA receptors does not dictate either an inhibitory or excitatory role for this 
metal, and thus, provides no clear basis for assigning it a role in seizure generation. As such, ZnR function in the hippocampus may represent a novel contributor to the overall regulation of neuronal excitability by $\mathrm{Zn}^{2+}$.

Effects of $\mathrm{Zn}^{2+}$ on synaptic plasticity and neuronal excitability, and effects of $\mathrm{Zn}^{2+}$ deficiency on learning and memory in mice and humans are well documented (Cole et al., 2000; Lopantsev et al., 2003; Smart et al., 2004; Kodirov et al., 2006). Since $\mathrm{ZnT} 3$ is considered the principal transport system for the loading of $\mathrm{Zn}^{2+}$ ions into synaptic vesicles, and knockout of this transporter completely eliminates $\mathrm{Zn}^{2+}$ from these vesicles (Frederickson et al., 2006; Linkous et al., 2008), the relatively mild phenotype characterizing ZnT3 KO mice has been somewhat unexpected. Our finding that the metabotropic $\mathrm{Ca}^{2+}$ response in slices from $\mathrm{ZnT} 3 \mathrm{KO}$ mice was unaffected by CaEDTA, suggests that it is not mediated via the $\mathrm{ZnR}$.

The metabotropic $\mathrm{Zn}^{2+}$-dependent activity we observed in CA3 neurons is remarkably similar to the extracellular $\mathrm{Zn}^{2+}$ dependent response we previously characterized in epithelial cells (Hershfinkel et al., 2001; Sharir and Hershfinkel, 2005; Dubi et al., 2008). The molecular identity of the receptor mediating this response had been unknown. The orphan GPCR GPR39 is a member of the ghrelin receptor family (McKee et al., 1997). Obestatin was initially proposed as the putative ligand for GPR39 (Zhang et al., 2005), yet, subsequent studies failed to confirm this (Lauwers et al., 2006). It was subsequently suggested that $\mathrm{Zn}^{2+}$ may directly interact with this receptor and enhance its signaling (Holst et al., 2004). The results presented here suggest that GPR39 may indeed directly mediate $\mathrm{Zn}^{2+}$-dependent signaling. The metal selectivity and dose dependence of the neuronal ZnR present in the hippocampus (Fig. 2), and those described for GPR39 (Yasuda et al., 2007) are strikingly similar. It has been reported, moreover, that GPR39 mRNA is expressed in the CNS, and specifically in the hippocampus (Jackson et al., 2006). Consistent with these findings, our immunofluorescence analysis indicates that GPR39 expression is highly enriched in the CA3 neurons that are postsynaptic to the $\mathrm{Zn}^{2+}$-rich mossy fibers, the same cells that mediate synaptically released $\mathrm{Zn}^{2+}$-dependent metabotropic activity. Thus, we propose that GPR39 is a critical component of $\mathrm{ZnR}$ metabotropic signaling, and, most likely, that GPR39 and $\mathrm{ZnR}$ are one and the same receptor.

In conclusion, we have identified $\mathrm{Zn}^{2+}$-dependent metabotropic activity in hippocampal CA3 neurons. This activity in brain areas rich in synaptic $\mathrm{Zn}^{2+}$ may represent the long-sought link between dynamic changes in extracellular $\mathrm{Zn}^{2+}$ and neuronal signaling mediated by this metal. Our data suggest that specific $\mathrm{Zn}^{2+}$-sensing receptor activity, putatively mediated by GPR39, triggers synaptic $\mathrm{Zn}^{2+}$-dependent metabotropic signaling in the CA3 region. This is the first evidence that $\mathrm{Zn}^{2+}$ is not only a modulatory ion, but acts via a specific postsynaptic receptor to trigger neuronal metabotropic signaling.

\section{References}

Aizenman E, Stout AK, Hartnett KA, Dineley KE, McLaughlin B, Reynolds IJ (2000) Induction of neuronal apoptosis by thiol oxidation: putative role of intracellular zinc release. J Neurochem 75:1878-1888.

An WL, Pei JJ, Nishimura T, Winblad B, Cowburn RF (2005) Zinc-induced anti-apoptotic effects in SH-SY5Y neuroblastoma cells via the extracellular signal-regulated kinase 1/2. Brain Res Mol Brain Res 135:40-47.

Azriel-Tamir H, Sharir H, Schwartz B, Hershfinkel M (2004) Extracellular zinc triggers ERK-dependent activation of $\mathrm{Na}+/ \mathrm{H}+$ exchange in colonocytes mediated by the zinc-sensing receptor. J Biol Chem 279:51804-51816.

Beierlein M, Fall CP, Rinzel J, Yuste R (2002) Thalamocortical bursts trigger recurrent activity in neocortical networks: layer 4 as a frequencydependent gate. J Neurosci 22:9885-9894.
Berkeley JL, Levey AI (2003) Cell-specific extracellular signal-regulated kinase activation by multiple $\mathrm{G}$ protein-coupled receptor families in hippocampus. Mol Pharmacol 63:128-135.

Bianchi R, Young SR, Wong RK (1999) Group I mGluR activation causes voltage-dependent and -independent $\mathrm{Ca} 2+$ rises in hippocampal pyramidal cells. J Neurophysiol 81:2903-2913.

Calderone A, Jover T, Mashiko T, Noh KM, Tanaka H, Bennett MV, Zukin RS (2004) Late calcium EDTA rescues hippocampal CA1 neurons from global ischemia-induced death. J Neurosci 24:9903-9913.

Canals M, Angulo E, Casadó V, Canela EI, Mallol J, Viñals F, Staines W, Tinner B, Hillion J, Agnati L, Fuxe K, Ferré S, Lluis C, Franco R (2005) Molecular mechanisms involved in the adenosine A and A receptorinduced neuronal differentiation in neuroblastoma cells and striatal primary cultures. J Neurochem 92:337-348.

Chen MJ, Nguyen TV, Pike CJ, Russo-Neustadt AA (2007) Norepinephrine induces BDNF and activates the PI-3K and MAPK cascades in embryonic hippocampal neurons. Cell Signal 19:114-128.

Cohen-Matsliah SI, Brosh I, Rosenblum K, Barkai E (2007) A novel role for extracellular signal-regulated kinase in maintaining long-term memoryrelevant excitability changes. J Neurosci 27:12584-12589.

Cole TB, Wenzel HJ, Kafer KE, Schwartzkroin PA, Palmiter RD (1999) Elimination of zinc from synaptic vesicles in the intact mouse brain by disruption of the ZnT3 gene. Proc Natl Acad Sci U S A 96:1716-1721.

Cole TB, Robbins CA, Wenzel HJ, Schwartzkroin PA, Palmiter RD (2000) Seizures and neuronal damage in mice lacking vesicular zinc. Epilepsy Res 39:153-169.

Cole TB, Martyanova A, Palmiter RD (2001) Removing zinc from synaptic vesicles does not impair spatial learning, memory, or sensorimotor functions in the mouse. Brain Res 891:253-265.

Côté A, Chiasson M, Peralta MR 3rd, Lafortune K, Pellegrini L, Tóth K (2005) Cell type-specific action of seizure-induced intracellular zinc accumulation in the rat hippocampus. J Physiol 566:821-837.

Domínguez MI, Blasco-Ibáñez JM, Crespo C, Marqués-Marí AI, MartínezGuijarro FJ (2003) Zinc chelation during non-lesioning overexcitation results in neuronal death in the mouse hippocampus. Neuroscience 116:791-806

Du L, Zhang X, Han YY, Burke NA, Kochanek PM, Watkins SC, Graham SH, Carcillo JA, Szabó C, Clark RS (2003) Intra-mitochondrial poly(ADPribosylation) contributes to NAD + depletion and cell death induced by oxidative stress. J Biol Chem 278:18426-18433.

Dubi N, Gheber L, Fishman D, Sekler I, Hershfinkel M (2008) Extracellular zinc and zinc-citrate, acting through a putative zinc sensing receptor, regulate growth and survival of prostate cancer cells. Carcinogenesis 29:1692-1700.

Frederickson CJ, Moncrieff DW (1994) Zinc-containing neurons. Biol Signals 3:127-139.

Frederickson CJ, Giblin LJ 3rd, Balaji RV, Rengarajan B, Masalha R, Frederickson CJ, Zeng Y, Lopez EV, Koh JY, Chorin U, Besser L, Hershfinkel M, Li Y, Thompson RB, Krezel A (2006) Synaptic release of zinc from brain slices: factors governing release, imaging, and accurate calculation of concentration. J Neurosci Methods 154:19-29.

Fukahori M, Itoh M (1990) Effects of dietary zinc status on seizure susceptibility and hippocampal zinc content in the El (epilepsy) mouse. Brain Res 529:16-22.

Giovannini MG (2006) The role of the extracellular signal-regulated kinase pathway in memory encoding. Rev Neurosci 17:619-634.

Grynkiewicz G, Poenie M, Tsien RY (1985) A new generation of Ca2+ indicators with greatly improved fluorescence properties. J Biol Chem 260:3440-3450.

Gundelfinger ED, Boeckers TM, Baron MK, Bowie JU (2006) A role for zinc in postsynaptic density asSAMbly and plasticity? Trends Biochem Sci 31:366-373.

Hansen MR, Bok J, Devaiah AK, Zha XM, Green SH (2003) Ca2+/ calmodulin-dependent protein kinases II and IV both promote survival but differ in their effects on axon growth in spiral ganglion neurons. J Neurosci Res 72:169-184.

Harris FM, Brecht WJ, Xu Q, Mahley RW, Huang Y (2004) Increased tau phosphorylation in apolipoprotein E4 transgenic mice is associated with activation of extracellular signal-regulated kinase: modulation by zinc. J Biol Chem 279:44795-44801.

Henkel G, Krebs B (2004) Metallothioneins: zinc, cadmium, mercury, and 
copper thiolates and selenolates mimicking protein active site featuresstructural aspects and biological implications. Chem Rev 104:801-824.

Hershfinkel M, Moran A, Grossman N, Sekler I (2001) A zinc-sensing receptor triggers the release of intracellular $\mathrm{Ca} 2+$ and regulates ion transport. Proc Natl Acad Sci U S A 98:11749-11754.

Hinkle PM, Kinsella PA, Osterhoudt KC (1987) Cadmium uptake and toxicity via voltage-sensitive calcium channels. J Biol Chem 262:16333-16337.

Holst B, Holliday ND, Bach A, Elling CE, Cox HM, Schwartz TW (2004) Common structural basis for constitutive activity of the ghrelin receptor family. J Biol Chem 279:53806-53817.

Holst B, Egerod KL, Schild E, Vickers SP, Cheetham S, Gerlach LO, Storjohann L, Stidsen CE, Jones R, Beck-Sickinger AG, Schwartz TW (2007) GPR39 signaling is stimulated by zinc ions but not by obestatin. Endocrinology 148:13-20.

Hosie AM, Dunne EL, Harvey RJ, Smart TG (2003) Zinc-mediated inhibition of GABA(A) receptors: discrete binding sites underlie subtype specificity. Nat Neurosci 6:362-369.

Huang YZ, Pan E, Xiong ZQ, McNamara JO (2008) Zinc-mediated transactivation of TrkB potentiates the hippocampal mossy fiber-CA3 pyramid synapse. Neuron 57:546-558.

Hwang JJ, Park MH, Choi SY, Koh JY (2005) Activation of the Trk signaling pathway by extracellular zinc: role of metalloproteinases. J Biol Chem 280:11995-12001.

Izumi Y, Auberson YP, Zorumski CF (2006) Zinc modulates bidirectional hippocampal plasticity by effects on NMDA receptors. J Neurosci 26:7181-7188.

Jackson VR, Nothacker HP, Civelli O (2006) GPR39 receptor expression in the mouse brain. Neuroreport 17:813-816.

Kan I, Ben-Zur T, Barhum Y, Levy YS, Burstein A, Charlow T, Bulvik S, Melamed E, Offen D (2007) Dopaminergic differentiation of human mesenchymal stem cells-utilization of bioassay for tyrosine hydroxylase expression. Neurosci Lett 419:28-33.

Kapur A, Yeckel M, Johnston D (2001) Hippocampal mossy fiber activity evokes $\mathrm{Ca} 2+$ release in CA3 pyramidal neurons via a metabotropic glutamate receptor pathway. Neuroscience 107:59-69.

Knöpfel T, Uusisaari M (2008) Modulation of excitation by metabotropic glutamate receptors. Results Probl Cell Differ 44:163-175.

Kodirov SA, Takizawa S, Joseph J, Kandel ER, Shumyatsky GP, Bolshakov VY (2006) Synaptically released zinc gates long-term potentiation in fear conditioning pathways. Proc Natl Acad Sci U S A 103:15218-15223.

Lauwers E, Landuyt B, Arckens L, Schoofs L, Luyten W (2006) Obestatin does not activate orphan $\mathrm{G}$ protein-coupled receptor GPR39. Biochem Biophys Res Commun 351:21-25.

Lengyel I, Fieuw-Makaroff S, Hall AL, Sim AT, Rostas JA, Dunkley PR (2000) Modulation of the phosphorylation and activity of calcium/calmodulindependent protein kinase II by zinc. J Neurochem 75:594-605.

Li Y, Hough CJ, Frederickson CJ, Sarvey JM (2001) Induction of mossy fiber $\rightarrow \mathrm{CA} 3$ long-term potentiation requires translocation of synaptically released $\mathrm{Zn}^{2+}$. J Neurosci 21:8015-8025.

Linkous DH, Flinn JM, Koh JY, Lanzirotti A, Bertsch PM, Jones BF, Giblin LJ, Frederickson CJ (2008) Evidence that the ZNT3 protein controls the total amount of elemental zinc in synaptic vesicles. J Histochem Cytochem 56:3-6.

Lopantsev V, Wenzel HJ, Cole TB, Palmiter RD, Schwartzkroin PA (2003) Lack of vesicular zinc in mossy fibers does not affect synaptic excitability of CA3 pyramidal cells in zinc transporter 3 knockout mice. Neuroscience 116:237-248.

Luo Y, DeFranco DB (2006) Opposing roles for ERK1/2 in neuronal oxidative toxicity: distinct mechanisms of ERK1/2 action at early versus late phases of oxidative stress. J Biol Chem 281:16436-16442.

McKee KK, Tan CP, Palyha OC, Liu J, Feighner SD, Hreniuk DL, Smith RG, Howard AD, Van der Ploeg LH (1997) Cloning and characterization of two human G protein-coupled receptor genes (GPR38 and GPR39) related to the growth hormone secretagogue and neurotensin receptors. Genomics 46:426-434.

McLaughlin B, Pal S, Tran MP, Parsons AA, Barone FC, Erhardt JA, Aizenman E (2001) p38 activation is required upstream of potassium current enhancement and caspase cleavage in thiol oxidant-induced neuronal apoptosis. J Neurosci 21:3303-3311.

Miyamoto E (2006) Molecular mechanism of neuronal plasticity: induction and maintenance of long-term potentiation in the hippocampus. J Pharmacol Sci 100:433-442.
Nagappan G, Woo NH, Lu B (2008) Ama "zinc" link between TrkB transactivation and synaptic plasticity. Neuron 57:477-479.

Nakamura T, Nakamura K, Lasser-Ross N, Barbara JG, Sandler VM, Ross WN (2000) Inositol 1,4,5-trisphosphate (IP3)-mediated $\mathrm{Ca}^{2+}$ release evoked by metabotropic agonists and backpropagating action potentials in hippocampal CA1 pyramidal neurons. J Neurosci 20:8365-8376.

Nicholls RE, Zhang XL, Bailey CP, Conklin BR, Kandel ER, Stanton PK (2006) mGluR2 acts through inhibitory Galpha subunits to regulate transmission and long-term plasticity at hippocampal mossy fiber-CA3 synapses. Proc Natl Acad Sci U S A 103:6380-6385.

Nimmerjahn A, Kirchhoff F, Kerr JN, Helmchen F (2004) Sulforhodamine 101 as a specific marker of astroglia in the neocortex in vivo. Nat Methods 1:31-37.

Palmiter RD, Cole TB, Quaife CJ, Findley SD (1996) ZnT-3, a putative transporter of zinc into synaptic vesicles. Proc Natl Acad Sci U S A 93:14934-14939.

Paoletti P, Ascher P, Neyton J (1997) High-affinity zinc inhibition of NMDA NR1-NR2A receptors. J Neurosci 17:5711-5725.

Paoletti P, Vergnano AM, Barbour B, Casado M (2009) Zinc at glutamatergic synapses. Neuroscience 158:126-136.

Pitsch J, Schoch S, Gueler N, Flor PJ, van der Putten H, Becker AJ (2007) Functional role of mGluR1 and mGluR4 in pilocarpine-induced temporal lobe epilepsy. Neurobiol Dis 26:623-633.

Qian J, Noebels JL (2005) Visualization of transmitter release with zinc fluorescence detection at the mouse hippocampal mossy fibre synapse. J Physiol 566:747-758.

Rachline J, Perin-Dureau F, Le Goff A, Neyton J, Paoletti P (2005) The micromolar zinc-binding domain on the NMDA receptor subunit NR2B. J Neurosci 25:308-317.

Rosenblum K, Futter M, Voss K, Erent M, Skehel PA, French P, Obosi L, Jones MW, Bliss TV (2002) The role of extracellular regulated kinases I/II in late-phase long-term potentiation. J Neurosci 22:5432-5441.

Rosenmund C, Stevens CF (1996) Definition of the readily releasable pool of vesicles at hippocampal synapses. Neuron 16:1197-1207.

Ruiz A, Walker MC, Fabian-Fine R, Kullmann DM (2004) Endogenous zinc inhibits GABA(A) receptors in a hippocampal pathway. J Neurophysiol 91:1091-1096.

Sekler I, Moran A, Hershfinkel M, Dori A, Margulis A, Birenzweig N, Nitzan Y, Silverman WF (2002) Distribution of the zinc transporter ZnT-1 in comparison with chelatable zinc in the mouse brain. J Comp Neurol 447:201-209.

Sensi SL, Jeng JM (2004) Rethinking the excitotoxic ionic milieu: the emerging role of $\mathrm{Zn}(2+)$ in ischemic neuronal injury. Curr Mol Med 4:87-111.

Sensi SL, Yin HZ, Carriedo SG, Rao SS, Weiss JH (1999) Preferential Zn2+ influx through $\mathrm{Ca} 2+$-permeable AMPA/kainate channels triggers prolonged mitochondrial superoxide production. Proc Natl Acad Sci U S A 96:2414-2419.

Seo SR, Chong SA, Lee SI, Sung JY, Ahn YS, Chung KC, Seo JT (2001) $\mathrm{Zn} 2+$-induced ERK activation mediated by reactive oxygen species causes cell death in differentiated PC12 cells. J Neurochem 78:600-610.

Sharir H, Hershfinkel M (2005) The extracellular zinc-sensing receptor mediates intercellular communication by inducing ATP release. Biochem Biophys Res Commun 332:845-852.

Smart TG, Hosie AM, Miller PS (2004) Zn2 + ions: modulators of excitatory and inhibitory synaptic activity. Neuroscientist 10:432-442.

Smith IF, Wiltgen SM, Parker I (2009) Localization of puff sites adjacent to the plasma membrane: functional and spatial characterization of $\mathrm{Ca}(2+)$ signaling in SH-SY5Y cells utilizing membrane-permeant caged IP(3). Cell Calcium 45:65-76.

Tan SE, Chen SS (1997) The activation of calcium/calmodulin-dependent protein kinase II after glutamate or potassium stimulation in hippocampal slices. Brain Res Bull 43:269-273.

Tang TS, Tu H, Chan EY, Maximov A, Wang Z, Wellington CL, Hayden MR, Bezprozvanny I (2003) Huntingtin and huntingtin-associated protein 1 influence neuronal calcium signaling mediated by inositol- $(1,4,5)$ triphosphate receptor type 1. Neuron 39:227-239.

Vogt K, Mellor J, Tong G, Nicoll R (2000) The actions of synaptically released zinc at hippocampal mossy fiber synapses. Neuron 26:187-196.

Volk LJ, Daly CA, Huber KM (2006) Differential roles for group $1 \mathrm{mGluR}$ subtypes in induction and expression of chemically induced hippocampal long-term depression. J Neurophysiol 95:2427-2438. 
Weiss JH, Sensi SL, Koh JY (2000) Zn(2+): a novel ionic mediator of neural injury in brain disease. Trends Pharmacol Sci 21:395-401.

White LD, Cory-Slechta DA, Gilbert ME, Tiffany-Castiglioni E, Zawia NH, Virgolini M, Rossi-George A, Lasley SM, Qian YC, Basha MR (2007) New and evolving concepts in the neurotoxicology of lead. Toxicol Appl Pharmacol 225:1-27.

Wu X, Zagranichnaya TK, Gurda GT, Eves EM, Villereal ML (2004) A TRPC1/TRPC3-mediated increase in store-operated calcium entry is required for differentiation of H19-7 hippocampal neuronal cells. J Biol Chem 279:43392-43402.

Xie X, Smart TG (1994) Modulation of long-term potentiation in rat hippocampal pyramidal neurons by zinc. Pflugers Arch 427:481-486.

Yamazaki Y, Fujii S, Nakamura T, Miyakawa H, Kudo Y, Kato H, Ito K (2002) Changes in $[\mathrm{Ca} 2+]$. (i) during adenosine triphosphate-induced synaptic plasticity in hippocampal CA1 neurons of the guinea pig. Neurosci Lett 324:65-68.
Yasuda S, Miyazaki T, Munechika K, Yamashita M, Ikeda Y, Kamizono A (2007) Isolation of $\mathrm{Zn} 2+$ as an endogenous agonist of GPR39 from fetal bovine serum. J Recept Signal Transduct Res 27:235-246.

Yin HZ, Sensi SL, Ogoshi F, Weiss JH (2002) Blockade of $\mathrm{Ca}^{2+}$-permeable AMPA/kainate channels decreases oxygen-glucose deprivation-induced $\mathrm{Zn}^{2+}$ accumulation and neuronal loss in hippocampal pyramidal neurons. J Neurosci 22:1273-1279.

Zhang JV, Ren PG, Avsian-Kretchmer O, Luo CW, Rauch R, Klein C, Hsueh AJ (2005) Obestatin, a peptide encoded by the ghrelin gene, opposes ghrelin's effects on food intake. Science 310:996-999.

Zhang Y, Wang H, Li J, Jimenez DA, Levitan ES, Aizenman E, Rosenberg PA (2004) Peroxynitrite-induced neuronal apoptosis is mediated by intracellular zinc release and 12-lipoxygenase activation. J Neurosci 24:10616-10627.

Zhang Y, Aizenman E, DeFranco DB, Rosenberg PA (2007) Intracellular zinc release, 12-lipoxygenase activation and MAPK dependent neuronal and oligodendroglial death. Mol Med 13:350-355. 